\title{
The lifetime of nitrogen oxides in an isoprene-dominated forest
}

Paul S. Romer ${ }^{1}$, Kaitlin C. Duffey ${ }^{1}$, Paul J. Wooldridge ${ }^{1}$, Hannah M. Allen ${ }^{2,3}$, Benjamin R. Ayres ${ }^{2}$, Steven S. Brown ${ }^{4}$, William H. Brune ${ }^{5}$, John D. Crounse ${ }^{6}$, Joost de Gouw ${ }^{4,7}$, Danielle C. Draper ${ }^{2,8}$, Philip A. Feiner ${ }^{5}$, Juliane L. Fry ${ }^{2}$, Allen H. Goldstein ${ }^{9,10}$, Abigail Koss ${ }^{4,7}$, Pawel K. Misztal ${ }^{10}$, Tran B. Nguyen $^{6,11}$, Kevin Olson ${ }^{10}$, Alex P. Teng ${ }^{6}$, Paul O. Wennberg ${ }^{6,12}$, Robert J. Wild ${ }^{4,7}$, Li Zhang ${ }^{5}$, and Ronald C. Cohen ${ }^{1,13}$

${ }^{1}$ Department of Chemistry, University of California at Berkeley, Berkeley, CA, USA

${ }^{2}$ Department of Chemistry, Reed College, Portland, OR, USA

${ }^{3}$ Division of Chemistry and Chemical Engineering, California Institute of Technology, Pasadena, CA, USA

${ }^{4}$ Chemical Sciences Division, Earth System Research Laboratory, National Oceanic and Atmospheric Administration, Boulder, CO, USA

${ }^{5}$ Department of Meteorology, Pennsylvania State University, University Park, PA, USA

${ }^{6}$ Division of Geological and Planetary Sciences, California Institute of Technology, Pasadena, CA, USA

${ }^{7}$ Cooperative Institute for Research in Environmental Sciences, University of Colorado, Boulder, CO, USA

${ }^{8}$ Department of Chemistry, University of California, Irvine, CA, USA

${ }^{9}$ Department of Civil and Environmental Engineering, University of California at Berkeley, Berkeley, CA, USA

${ }^{10}$ Department of Environmental Science, Policy and Management, University of California at Berkeley, Berkeley, CA, USA

${ }^{11}$ Department of Environmental Toxicology, University of California, Davis, CA, USA

${ }^{12}$ Division of Engineering and Applied Science, California Institute of Technology, Pasadena, CA, USA

${ }^{13}$ Department of Earth and Planetary Sciences, University of California at Berkeley, Berkeley, CA, USA

Correspondence to: Ronald C. Cohen (rccohen@berkeley.edu)

Received: 12 January 2016 - Published in Atmos. Chem. Phys. Discuss.: 21 January 2016

Revised: 4 May 2016 - Accepted: 16 May 2016 - Published: 23 June 2016

\begin{abstract}
The lifetime of nitrogen oxides $\left(\mathrm{NO}_{x}\right)$ affects the concentration and distribution of $\mathrm{NO}_{x}$ and the spatial patterns of nitrogen deposition. Despite its importance, the lifetime of $\mathrm{NO}_{x}$ is poorly constrained in rural and remote continental regions. We use measurements from a site in central Alabama during the Southern Oxidant and Aerosol Study (SOAS) in summer 2013 to provide new insights into the chemistry of $\mathrm{NO}_{x}$ and $\mathrm{NO}_{x}$ reservoirs. We find that the lifetime of $\mathrm{NO}_{x}$ during the daytime is controlled primarily by the production and loss of alkyl and multifunctional nitrates ( $\Sigma$ ANs). During SOAS, $\Sigma$ AN production was rapid, averaging $90 \mathrm{ppth}^{-1}$ during the day, and occurred predominantly during isoprene oxidation. Analysis of the $\Sigma \mathrm{AN}$ and $\mathrm{HNO}_{3}$ budgets indicate that $\Sigma$ ANs have an average lifetime of under $2 \mathrm{~h}$, and that approximately $45 \%$ of the $\Sigma$ ANs produced at this site are rapidly hydrolyzed to produce nitric acid. We find that $\Sigma \mathrm{AN}$ hydrolysis is the largest source of $\mathrm{HNO}_{3}$ and the primary pathway to permanent removal of $\mathrm{NO}_{x}$ from the boundary layer in this location. Using these new constraints
\end{abstract}

on the fate of $\Sigma$ ANs, we find that the $\mathrm{NO}_{x}$ lifetime is $11 \pm 5 \mathrm{~h}$ under typical midday conditions. The lifetime is extended by storage of $\mathrm{NO}_{x}$ in temporary reservoirs, including acyl peroxy nitrates and $\Sigma$ ANs.

\section{Introduction}

The concentration and chemistry of nitrogen oxides $\left(\mathrm{NO}_{x} \equiv \mathrm{NO}+\mathrm{NO}_{2}\right)$ in Earth's troposphere has a significant and non-linear effect on the oxidative capacity of the atmosphere. This in turn affects the production, composition, and aging of aerosols and the lifetime of greenhouse gases such as methane. Concentrations of $\mathrm{NO}_{x}$ control the production of ozone, a respiratory health hazard, important oxidant, and greenhouse gas. In addition, the deposition of reactive nitrogen is an important source of nutrients in some ecosystems (e.g. Fowler et al., 2013). 
$\mathrm{NO}_{x}$ is emitted by both anthropogenic and biogenic sources, including motor vehicles, power plants, forest fires, and soil bacteria (e.g. Dallmann and Harley, 2010; Mebust and Cohen, 2014; Hudman et al., 2012), and is temporarily or permanently removed from the atmosphere by chemical conversion to higher oxides of nitrogen. Across much of the globe, the balance of these sources and sinks is in a period of dramatic change, with large reductions of $\mathrm{NO}_{x}$ emissions occurring in North America and Europe and significant increases occurring in Asia (e.g. Russell et al., 2012; Curier et al., 2014; Reuter et al., 2014). Understanding the effects of changes in $\mathrm{NO}_{x}$ emissions on the concentration and spatial distribution of $\mathrm{NO}_{x}$ requires detailed knowledge of the chemistry and transport of $\mathrm{NO}_{x}$ and $\mathrm{NO}_{x}$ reservoirs. These reservoirs are poorly understood and represent a significant uncertainty in analyses of $\mathrm{NO}_{x}$ emissions and ozone production (e.g. Ito et al., 2007; Browne and Cohen, 2012; Mao et al., 2013).

The net chemical loss of $\mathrm{NO}_{x}$ is difficult to directly observe. Observational methods for determining the lifetime of $\mathrm{NO}_{x}$ are easiest to apply in the outflow of isolated emissions, where the declining concentration of $\mathrm{NO}_{x}$ or the changing ratio of $\mathrm{NO}_{x}$ to total reactive nitrogen $\left(\mathrm{NO}_{y}\right)$ provide clear evidence for $\mathrm{NO}_{x}$ loss (e.g. Ryerson et al., 1998; Dillon et al., 2002; Alvarado et al., 2010; Valin et al., 2013). In rural and remote regions, emissions and concentrations of $\mathrm{NO}_{x}$ and $\mathrm{NO}_{y}$ are typically slowly varying over large distances (e.g. Browne et al., 2013), preventing the loss of $\mathrm{NO}_{x}$ from being directly observable. Nor can the lifetimes found in plume studies be easily translated into an appropriate lifetime in the regional background. Short-lived $\mathrm{NO}_{x}$ reservoirs such as peroxy acyl nitrate (PAN) can efficiently remove $\mathrm{NO}_{x}$ in a plume, but act as a source of $\mathrm{NO}_{x}$ in rural and remote regions (Finlayson-Pitts and Pitts, 1999). In addition, the non-linear interactions between $\mathrm{NO}_{x}$ and $\mathrm{OH}$ make the lifetime of $\mathrm{NO}_{x}$ in a fresh plume very different from its lifetime several hours downwind (e.g. Martinez et al., 2003; Valin et al., 2013).

To constrain the lifetime of $\mathrm{NO}_{x}$ in rural and remote regions, observations of reactive nitrogen species must be combined with an understanding of the chemical transformations between $\mathrm{NO}_{x}$ and its higher oxides. If the production, loss, and fate of these higher oxides are accurately understood, then the lifetime of $\mathrm{NO}_{x}$ can be calculated by tracing the flow of reactive nitrogen through the system. Here, we evaluate the daytime lifetime of $\mathrm{NO}_{x}$ in the rural southeastern United States, using measurements taken from 1 June-15 July 2013 as part of the Southern Oxidant and Aerosol Study (SOAS). In situ measurements of volatile organic compounds (VOCs), atmospheric oxidants, and a wide range of reactive nitrogen compounds are used to determine the production and loss rates for nitric acid, alkyl and multifunctional nitrates, and peroxy nitrates. These rates are used to assess the lifetime of $\mathrm{NO}_{x}$ in this region.

\section{The $\mathrm{NO}_{y}$ family and the lifetime of $\mathrm{NO}_{x}$}

During the day, $\mathrm{NO}_{x}$ is lost by associating with other radicals to produce higher oxides of nitrogen, primarily nitric acid, alkyl and multifunctional nitrates $\left(\Sigma \mathrm{ANs}=\Sigma \mathrm{RONO}_{2}\right)$, and peroxy nitrates $\left(\Sigma \mathrm{PNs}=\Sigma \mathrm{R}(\mathrm{O}) \mathrm{OONO}_{2}\right)$ (e.g. Day et al., 2003; Perring et al., 2010). The sum of these and other higher oxides such as $\mathrm{N}_{2} \mathrm{O}_{5}$ and $\mathrm{HONO}$ are collectively known as $\mathrm{NO}_{z}\left(\mathrm{NO}_{z} \equiv \mathrm{NO}_{y}-\mathrm{NO}_{x}\right)$.

$\mathrm{NO}_{x}$ is oxidized to produce the major daytime classes of $\mathrm{NO}_{z}$ through Reactions (R1), (R2b), and (R3).

$$
\begin{aligned}
& \mathrm{NO}_{2}+\mathrm{OH}+M \rightarrow \mathrm{HNO}_{3}+M \\
& \mathrm{NO}+\mathrm{RO}_{2}+M \rightarrow \mathrm{RONO}_{2}+M \\
& \mathrm{NO}_{2}+\mathrm{R}(\mathrm{O}) \mathrm{O}_{2}+M \rightleftharpoons \mathrm{R}(\mathrm{O}) \mathrm{OONO}_{2}+M
\end{aligned}
$$

$\mathrm{NO}_{x}$ can also be converted to $\mathrm{NO}_{z}$ through reactions of the $\mathrm{NO}_{3}$ radical. Although these reactions are most important at night, previous studies have shown that $\mathrm{NO}_{3}$ chemistry can produce $\mathrm{NO}_{z}$ during the day if concentrations of alkenes are high (e.g. Fuentes et al., 2007; Mogensen et al., 2015; Ayres et al., 2015).

The production and fate of different $\mathrm{NO}_{z}$ species determine the lifetime of $\mathrm{NO}_{x}$. Some of these species are shortlived and re-release $\mathrm{NO}_{x}$ back to the atmosphere within hours of being formed. If the lifetime for the conversion of an $\mathrm{NO}_{z}$ species back to $\mathrm{NO}_{x}$ is shorter than typical $\mathrm{NO}_{x}$ lifetimes in the atmosphere, then $\mathrm{NO}_{x}$ and these $\mathrm{NO}_{z}$ species interact, and their concentrations will approach a steady-state ratio. As $\mathrm{NO}_{x}$ is removed from the system, some of the shortlived $\mathrm{NO}_{z}$ species dissociate, buffering the concentration of $\mathrm{NO}_{x}$. In this way, the presence of $\mathrm{NO}_{x}$ reservoirs directly extends the lifetime of $\mathrm{NO}_{x}$.

One method to take this buffering into account when calculating the lifetime of $\mathrm{NO}_{x}$ is to consider the sum of $\mathrm{NO}_{x}$ and all $\mathrm{NO}_{z}$ species with lifetimes to re-release of $\mathrm{NO}_{x}$ shorter than the atmospheric lifetime of $\mathrm{NO}_{x}$. We define this sum as short-lived reactive nitrogen, or $\mathrm{NO}_{\mathrm{SL}}$. The remaining forms of reactive nitrogen are defined as long-lived reactive nitrogen $\left(\mathrm{NO}_{\mathrm{LL}}\right)$. The division between $\mathrm{NO}_{\mathrm{SL}}$ and $\mathrm{NO}_{\mathrm{LL}}$ depends on the lifetime of $\mathrm{NO}_{x}$. For the initial discussion in this manuscript, we use a provisional lifetime of $7 \mathrm{~h}$ to divide $\mathrm{NO}_{z}$ species between $\mathrm{NO}_{\mathrm{SL}}$ and $\mathrm{NO}_{\mathrm{LL}}$. This cutoff is in the middle of the range of $\mathrm{NO}_{x}$ lifetimes found in plume studies (e.g. Ryerson et al., 1998; Dillon et al., 2002; Alvarado et al., 2010; Valin et al., 2013). The provisional cutoff chosen as a starting point does not affect the final results.

In areas well removed from large $\mathrm{NO}_{x}$ sources, $\mathrm{NO}_{x}$ and its short-lived reservoirs interconvert significantly faster than the rate of change of $\mathrm{NO}_{x}$. Under these conditions, the lifetime of $\mathrm{NO}_{x}\left(\tau_{\mathrm{NO}_{x}}\right)$ is equal to the lifetime of $\mathrm{NO}_{\mathrm{SL}}$. If the conversion of $\mathrm{NO}_{\mathrm{LL}}$ to $\mathrm{NO}_{\mathrm{SL}}$ is negligible, then the lifetime of $\mathrm{NO}_{x}$ can be calculated by Eq. (1).

$$
\tau_{\mathrm{NO}_{x}}=\tau_{\mathrm{NO}_{\mathrm{SL}}}=\frac{\left[\mathrm{NO}_{\mathrm{SL}}\right]}{\mathcal{L}\left(\mathrm{NO}_{\mathrm{SL}}\right)}
$$




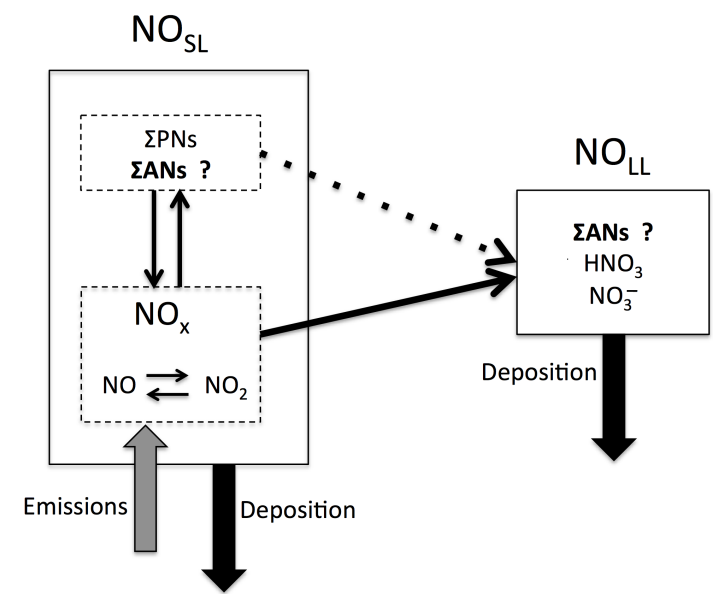

Figure 1. A schematic representation of the chemistry of $\mathrm{NO}_{\mathrm{SL}}$ and $\mathrm{NO}_{\mathrm{LL}}$, showing the typical components of both classes.

Throughout this paper, we use $\mathcal{L}(X)$ to indicate the gross loss rate of the compound or class of compounds $X$.

The relationship and interactions between $\mathrm{NO}_{\mathrm{SL}}$ and $\mathrm{NO}_{\mathrm{LL}}$, and their typical compositions in the planetary boundary layer, are shown in Fig. 1. In the summertime at midlatitudes, peroxy nitrates typically release $\mathrm{NO}_{x}$ within hours of being formed (LaFranchi et al., 2009), making them a component of $\mathrm{NO}_{\mathrm{SL}}$. Under these same conditions, nitric acid typically converts back to $\mathrm{NO}_{x}$ on timescales of $100 \mathrm{~h}$ or greater (Finlayson-Pitts and Pitts, 1999) and is a component of $\mathrm{NO}_{\mathrm{LL}}$. The fate and lifetime of $\Sigma$ ANs, the third major component of $\mathrm{NO}_{z}$, remain poorly understood, making it uncertain whether $\Sigma$ ANs act as a component of $\mathrm{NO}_{\mathrm{SL}}$ or $\mathrm{NO}_{\mathrm{LL}}$ (Perring et al., 2013, and references therein). This is especially true for the multifunctional, biogenically derived nitrates that are the predominant component of $\Sigma$ ANs in forested areas (e.g. Beaver et al., 2012).

Recent studies of multifunctional nitrates suggest that the main daytime loss pathways of these species are deposition, reaction with $\mathrm{OH}$, photolysis, and heterogeneous hydrolysis to produce nitric acid (e.g. Darer et al., 2011; Browne et al., 2013; Lee et al., 2014; Müller et al., 2014; Nguyen et al., 2015; Lee et al., 2016). These recent studies, combined with the extensive measurements made during SOAS, allow us to provide new constraints on the lifetime and fate of $\Sigma$ ANs and therefore to more accurately determine the lifetime of $\mathrm{NO}_{x}$.

\section{Instrumentation and measurements}

The primary ground site for SOAS was located in Bibb County, Alabama $\left(32.90289^{\circ} \mathrm{N}, 87.24968^{\circ} \mathrm{W}\right)$ at the Centreville (CTR) long-term monitoring site in the SouthEastern Aerosol Research and CHaracterization (SEARCH) Network (Hansen et al., 2003). This location is $40 \mathrm{~km}$ southeast of Tuscaloosa (population 95000 ), and $90 \mathrm{~km}$ southwest of
Birmingham (population 210000 ). Comparison with longterm measurements indicate that the summer of 2013 was cooler and cloudier than typical for previous summers (Hidy et al., 2014). Gas-phase measurements used in this study were located on a $20 \mathrm{~m}$ walk-up tower at the edge of the forest. Nitrate ion and meteorological parameters were measured in a clearing approximately $50 \mathrm{~m}$ away from the tower.

A nearly complete suite of reactive nitrogen species, including $\mathrm{NO}, \mathrm{NO}_{2}, \Sigma \mathrm{PNs}, \Sigma \mathrm{ANs}, \mathrm{HNO}_{3}$, and $\mathrm{NO}_{3}^{-}$, was measured during SOAS. NO was measured using the chemiluminescence instrument described in Min et al. (2014). The reaction of ambient $\mathrm{NO}$ with added excess $\mathrm{O}_{3}$ formed excited $\mathrm{NO}_{2}^{*}$ molecules. A fraction of these fluoresce, and the emitted photons were collected on a red-sensitive photomultiplier tube (Hamamatsu H7421-50). Calibrations were performed every $2 \mathrm{~h}$ by diluting NO standard gas $(5.08 \mathrm{ppm} \pm 5 \% \mathrm{NO}$ in $\mathrm{N}_{2}$, Praxair) to $3-20 \mathrm{ppb}$ in zero air and adding it to the instrument inlet. The mixing ratio was corrected for enhanced quenching by water vapor (Thornton et al., 2000) using colocated measurements of relative humidity and temperature.

$\mathrm{NO}_{2}, \Sigma$ PNs, and $\Sigma$ ANs were measured via thermal dissociation laser induced fluorescence (TD-LIF), as described by Day et al. (2002). Ambient air was drawn into a multipass White cell, where a $532 \mathrm{~nm}$ Nd-YAG laser excited the $\mathrm{NO}_{2}$ molecules, and their fluorescence signal was collected on a photomultiplier tube (Hamamatsu H7421-50). The same instrument was used to measure the sum of peroxy nitrates and the sum of alkyl and multifunctional nitrates by first passing the air through a heated oven, where the organic nitrates dissociated to form $\mathrm{NO}_{2}$. Organic nitrates present in the particle phase undergo evaporation and thermal dissociation in the heated ovens to form $\mathrm{NO}_{2}$. The TD-LIF measurement of $\Sigma$ ANs therefore includes alkyl and multifunctional nitrates in both the gas and particle phases, but does not include $\mathrm{HNO}_{3}$ or particle-phase inorganic nitrate (Day et al., 2002; Rollins et al., 2010). All of the channels were calibrated by injecting $\mathrm{NO}_{2}$ standard gas $\left(5.03 \mathrm{ppm} \pm 5 \% \mathrm{NO}_{2}\right.$ in $\mathrm{N}_{2}$, Praxair) and corrected for enhanced quenching by water vapor.

Nitric acid was measured in the gas phase by chemical ionization mass spectrometry (CIMS), using $\mathrm{CF}_{3} \mathrm{O}^{-}$as the reagent ion (Crounse et al., 2006). The ions were quantified using a compact time-of-flight mass spectrometer, and the instrument was calibrated in the field using isotopically labeled nitric acid. Particle-phase inorganic nitrate $\left(\mathrm{NO}_{3}^{-}\right)$was measured using a Monitor for AeRosols and GAses (MARGA) (Allen et al., 2015). Ambient air was drawn through a rotating wet-walled denuder which collected water-soluble gasphase compounds. Particle-phase compounds were captured by a steam-jet aerosol collector downstream of the denuder. Water-soluble ions from both phases were then quantified via ion chromatography. This measurement of $\mathrm{NO}_{3}^{-}$is designed to be specific to inorganic nitrate, and is not affected by $\Sigma$ ANs in the particle phase (Allen et al., 2015). 

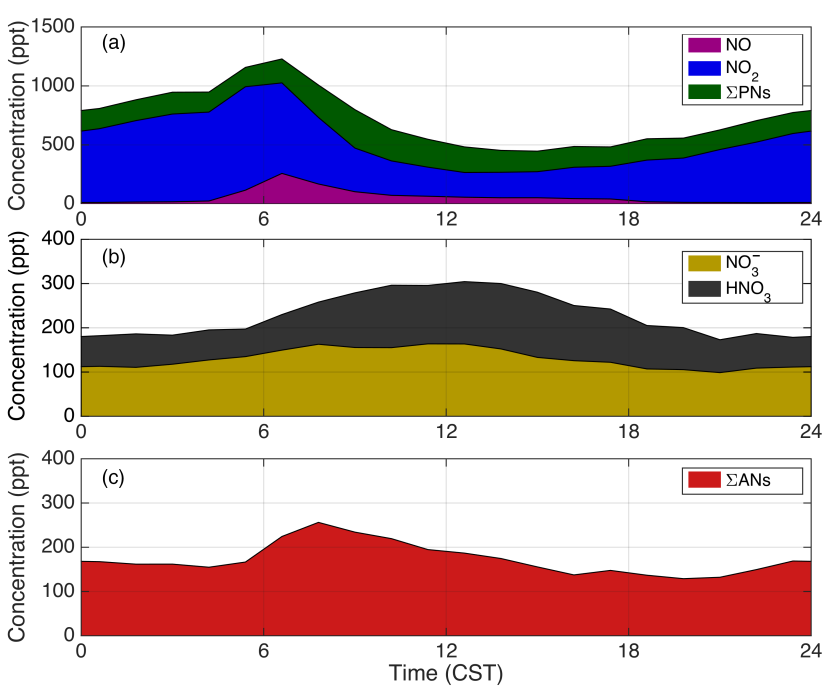

Figure 2. Diurnal cycle of measured reactive nitrogen species during SOAS. Reactive nitrogen species are classified as likely components of $\mathrm{NO}_{\mathrm{SL}}$ (a), likely components of $\mathrm{NO}_{\mathrm{LL}}$ (b) or unknown (c). The classification into $\mathrm{NO}_{\mathrm{SL}}$ and $\mathrm{NO}_{\mathrm{LL}}$ is based on typical summertime afternoon lifetimes. The measurement of $\mathrm{HNO}_{3}$ represents nitric acid in the gas phase, while the measurement of $\mathrm{NO}_{3}^{-}$represents inorganic nitrate in the particle phase. The measurement of $\Sigma$ ANs includes alkyl and multifunctional nitrates in both the gas and particle phase.

Measurements of reactive nitrogen species are summarized in Fig. 2. Concentrations of $\mathrm{NO}_{\mathrm{SL}}$ compounds (NO, $\mathrm{NO}_{2}$, and $\Sigma \mathrm{PNs}$ ) are shown in Fig. 2a. Afternoon concentrations of $\mathrm{NO}_{2}$ and $\mathrm{NO}$ were typically around 220 and $50 \mathrm{ppt}$ respectively. After sunset, $\mathrm{NO}$ dropped to near zero, and $\mathrm{NO}_{2}$ began to increase. At sunrise, NO concentrations rapidly rose to over 200 ppt between 06:00 and 08:00 Central Standard Time (CST) while $\mathrm{NO}_{2}$ decreased sharply. By 11:00, when the daytime boundary layer was well developed, the concentrations of $\mathrm{NO}$ and $\mathrm{NO}_{2}$ returned to their typical afternoon values. Concentrations of $\Sigma$ PNs were $160 \mathrm{ppt}$ at sunrise, increased to a maximum concentration of 300 ppt at 09:00 and declined slowly throughout the rest of the day.

Concentrations of $\mathrm{HNO}_{3}$ and inorganic $\mathrm{NO}_{3}^{-}$, components of $\mathrm{NO}_{\mathrm{LL}}$, are shown in Fig. 2b. Both species increased slowly after sunrise and reached a maximum combined concentration of $300 \mathrm{ppt}$ at 13:00, before declining to a combined concentration of $175 \mathrm{ppt}$ at night. The total concentration of $\Sigma$ ANs in both the gas and particle phase, whose partitioning into $\mathrm{NO}_{\mathrm{SL}}$ and $\mathrm{NO}_{\mathrm{LL}}$ is not known, is shown in Fig. 2c. $\Sigma$ ANs averaged $150 \mathrm{ppt}$ during the night and increased sharply after sunrise. After reaching a maximum of $250 \mathrm{ppt}$ at 08:00, $\Sigma$ ANs declined slowly to a minimum concentration of $125 \mathrm{ppt}$ at sunset.

$\mathrm{OH}, \mathrm{HO}_{2}$, and $\mathrm{OH}$ reactivity (OHR) were measured via fluorescence assay by gas expansion (FAGE) of $\mathrm{OH}$. A $308 \mathrm{~nm}$ dye laser excited the $\mathrm{OH}$ radicals and their fluores-

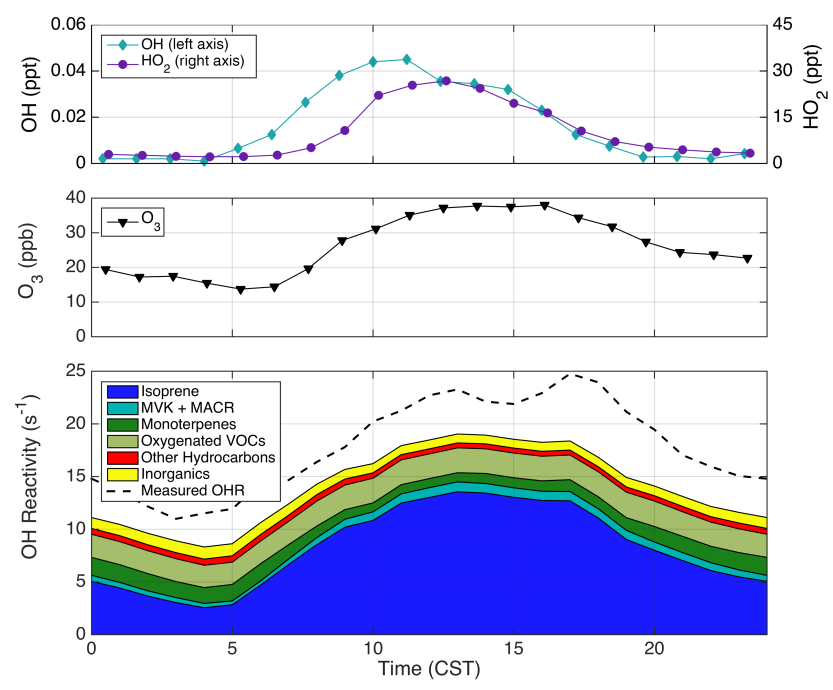

Figure 3. Diurnal cycle of $\mathrm{OH}, \mathrm{HO}_{2}, \mathrm{O}_{3}$ and VOCs during SOAS. The top plot shows the concentration of $\mathrm{OH}$ and $\mathrm{HO}_{2}$; the middle plot shows the concentration of $\mathrm{O}_{3}$; the bottom plot shows the $\mathrm{OH}$ reactivity.

cence was detected by an electronically gated microchannel plate detector (Faloona et al., 2004). Calibration of the system was performed by in situ generation of $\mathrm{OH}$ radicals via photolysis of water vapor. Chemical zeroing was performed by periodically adding $\mathrm{C}_{3} \mathrm{~F}_{6}$ to the sampling inlet in order to quantify the interference from internally generated $\mathrm{OH}$ observed in previous field campaigns (Mao et al., 2012). $\mathrm{HO}_{2}$ was measured in a second channel by adding NO to chemically convert $\mathrm{HO}_{2}$ to $\mathrm{OH}$. The amount of added $\mathrm{NO}$ was regulated such that $\mathrm{HO}_{2}$ but not $\mathrm{RO}_{2}$ was converted to $\mathrm{OH}$ (Fuchs et al., 2011). Total OH reactivity (OHR) was measured by drawing ambient air through a flow tube and mixing it with a fixed concentration of $\mathrm{OH}$. At the end of the flow tube, the concentration of $\mathrm{OH}$ was measured. The $\mathrm{OH}$ reactivity is determined by the slope of the $\mathrm{OH}$ signal vs. reaction time (Mao et al., 2009).

Measured concentrations of $\mathrm{OH}$ peaked at $0.045 \mathrm{ppt}$ and concentrations of $\mathrm{HO}_{2}$ at $30 \mathrm{ppt}$ during SOAS (Fig. 3, top panel). Both $\mathrm{OH}$ and $\mathrm{HO}_{2}$ increased slowly throughout the morning and reached their maximum in the early afternoon. Concentrations then fell as the sun set, with $\mathrm{OH}$ usually dropping below $0.01 \mathrm{ppt}$ by 19:00 The measured $\mathrm{OH}$ reactivity was high, reaching an afternoon peak of close to $25 \mathrm{~s}^{-1}$ (Fig. 3, bottom panel). OHR decreased throughout the night, reaching a minimum of $10 \mathrm{~s}^{-1}$ just before sunrise.

Measurements of ozone were made using a cavity ring down spectrometer (Washenfelder et al., 2011). $\mathrm{O}_{3}$ was chemically converted to $\mathrm{NO}_{2}$ by reaction with excess $\mathrm{NO}$, and the resulting $\mathrm{NO}_{2}$ was measured by cavity ring-down spectroscopy at $404 \mathrm{~nm}$. The concentration of ozone increased from a minimum of $15 \mathrm{ppb}$ at sunrise to a maximum of $38 \mathrm{ppb}$ in the late afternoon (Fig. 3, middle panel). 
Volatile organic compounds were measured primarily by gas chromatography-mass spectrometry (GC-MS). Samples were collected in a liquid-nitrogen cooled trap for $5 \mathrm{~min}$, and then transferred by heating onto an analytical column, and detected using an electron-impact quadrupole massspectrometer (Goldan et al., 2004; Gilman et al., 2010). This system was able to quantify a wide range of compounds including alkanes, alkenes, aromatics, isoprene, and multiple monoterpenes. The sum of methyl vinyl ketone (MVK) and methacrolein (MACR) was measured using a proton transfer reaction time-of-flight mass spectrometer (PTR-TOF-MS) (Kaser et al., 2013). The interference in this measurement from the decomposition of isoprene hydroperoxides on instrument inlets (Rivera-Rios et al., 2014) is not corrected for, and increases the uncertainty in this measurement by approximately $20 \%$.

VOC measurements at the site show that the OHR was dominated by reaction with biogenic compounds. Figure 3 shows the $\mathrm{OH}$ reactivity of individually measured compounds as a stacked area plot. In the daytime, isoprene accounted for nearly half of the total reactivity, while VOCs typically attributed to anthropogenic activities, including alkanes, aromatics, and simple alkenes, were responsible for less than $10 \%$ of the measured OHR. Not included in Fig. 3 is the reactivity of VOCs whose reaction with $\mathrm{OH}$ does not lead to net loss of $\mathrm{OH}$, and therefore does not contribute to the measured OHR. These compounds, primarily isoprene hydroperoxides (ISOPOOH) and C5hydroxyaldehydes (HPALD), have an average daytime reactivity of $2 \mathrm{~s}^{-1}$. The sum of individual reactivities shows a similar diurnal pattern to the measured OHR, and accounts for $70-85 \%$ of the total. Unknown biogenic emissions, small aldehydes and alcohols, and other 2nd and 3rd generation VOC oxidation products are all possible contributors to the missing reactivity (e.g. Di Carlo et al., 2004; Goldstein and Galbally, 2007; Pusede et al., 2014; Kaiser et al., 2016). Meteorological parameters including temperature and solar radiation were measured by Atmospheric Research and Analysis as part of SEARCH.

\section{The production and loss of individual $\mathrm{NO}_{x}$ reservoirs}

\subsection{Nitric acid}

In the boundary layer, the production of nitric acid is typically followed by deposition and thus leads to the permanent removal of reactive nitrogen from the atmosphere. Nitric acid can undergo photolysis or reaction with $\mathrm{OH}$ to produce $\mathrm{NO}_{x}$, but these processes are slow (Burkholder et al., 1993; Atkinson et al., 2006), with an average calculated rate during SOAS of less than $0.2 \mathrm{ppt} \mathrm{h}^{-1}$. Gas-phase nitric acid can also partition into aerosols. Nitric acid is long-lived in the particle phase and is typically lost by re-evaporation into the gas phase (e.g. Hennigan et al., 2008). The loss of ni- tric acid through deposition of aerosols is typically negligible compared to its gas-phase deposition (e.g. Zalakeviciute et al., 2012). Because nitric acid releases $\mathrm{NO}_{x}$ so slowly, it is a component of $\mathrm{NO}_{\mathrm{LL}}$.

The deposition velocity $\left(v_{\text {dep }}\right)$ of $\mathrm{HNO}_{3}$ in the gas phase was measured during SOAS by Nguyen et al. (2015). Around midday, when the boundary layer is well developed, the deposition velocity can be combined with the boundary layer height (BLH) to calculate a loss rate of using Eq. (2).

$\mathcal{L}\left(\mathrm{HNO}_{3}\right)=\frac{v_{\mathrm{dep}}}{\mathrm{BLH}} \cdot\left[\mathrm{HNO}_{3}\right]$

Using this method, we find the lifetime of nitric acid in the gas and particle phase to be $6 \mathrm{~h}$ at noon. In the late afternoon, changing boundary layer dynamics make this calculation of the loss rate inaccurate (e.g. Papale et al., 2006; Millet et al., 2015). The loss of nitric acid in the late afternoon was therefore calculated by fitting periods of consistent decay between 15:00 and 19:00 with an exponential curve. By fitting only the periods of consistent decay, we aim to select for periods where the production of nitric acid is at a minimum and the observed net decay of nitric acid is similar to its gross loss rate. Because nitric acid reversibly partitions between the gas and particle phases, the lifetime was calculated based on the concentration of nitric acid in both phases. The lifetime calculated using this method is $5_{-2}^{+3} \mathrm{~h}$, similar to the lifetime of nitric acid calculated using Eq. (2) at noon.

By combining the loss rate of nitric acid with the rate of change of its concentration, we can calculate an inferred production rate of nitric acid (Fig. 4). This inferred production rate for each hour is defined as the difference between the rate of change in the concentration of nitric acid and the loss rate. The rate of change was determined as the slope of a best-fit line of the concentration of nitric acid vs. time for each hour.

Since the calculation of the inferred production rate considers only the hour-to-hour change in nitric acid and not its gross concentration, the inferred production rate is not affected by distant nitric acid sources. We find very little (less than $15 \%$ ) variation in the concentration of $\mathrm{NO}_{x}$ with wind direction and no correlation of the inferred production rate around noon with sulfate (a power plant tracer) or benzene (an urban tracer). As the transport time from these sources to the CTR site is significantly greater than $1 \mathrm{~h}$, this result is not surprising. The changing boundary layer height could significantly impact the inferred production rate of nitric acid during the early morning, but it is likely unimportant at midday.

Also shown in Fig. 4 is the rate of nitric acid production from the reaction of $\mathrm{OH}+\mathrm{NO}_{2}$ (Reaction $\left.\mathrm{R} 1\right)$, using the rate constant measured by Mollner et al. (2010). The vertical bars for the inferred rate represent the combined effects of the uncertainty in both the fit of concentration vs. time and in the calculated nitric acid lifetime, as well as the day-to-day variations in the observations. The vertical bars shown for the production of nitric acid from the $\mathrm{OH}+\mathrm{NO}_{2}$ reaction in- 


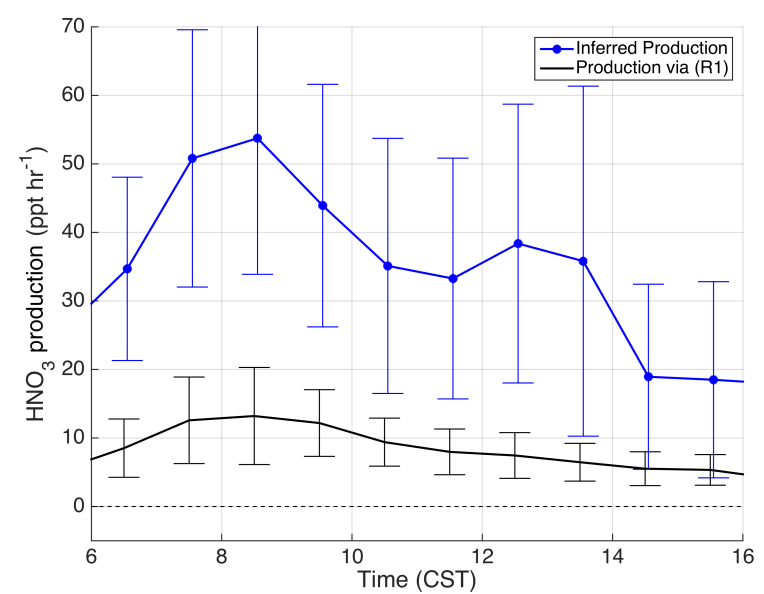

Figure 4. Production rates of nitric acid during SOAS calculated from the reaction of $\mathrm{OH}+\mathrm{NO}_{2}$ (black) and inferred from the concentration and deposition rate of nitric acid (blue). The vertical bars show the systematic and random uncertainty in the calculated rates, as described in the text.

clude both the systematic and random errors in the measurements of $\mathrm{OH}$ and $\mathrm{NO}_{2}$ and in the rate coefficient, $k_{\mathrm{OH}+\mathrm{NO}_{2}}$, combined in quadrature.

Between 10:00 and 14:00, when photochemistry is most active, the inferred production rate is 3-4 times larger than the rate of Reaction (R1), a difference of approximately $30 \mathrm{ppth}^{-1}$. The most likely explanation for the missing nitric acid production during this time is the heterogeneous hydrolysis of $\Sigma$ ANs. This reaction has been proposed as an important source of nitric acid over the Canadian boreal forest (Browne et al., 2013), and the hydrolysis of tertiary alkyl nitrates on atmospherically relevant timescales has been observed in several laboratory experiments (e.g. Darer et al., 2011; Liu et al., 2012; Rindelaub et al., 2015). If $\Sigma$ ANs are being converted to nitric acid, this process should appear as a sink in the budget of $\Sigma$ ANs. If other processes are responsible for the missing nitric acid source, these would not affect the budget of $\Sigma$ ANs. Only the conversion of $\Sigma$ ANs to nitric acid will lead to a missing source of nitric acid and a missing sink of $\Sigma$ ANs.

\subsection{Alkyl and multifunctional nitrates}

Previous observational studies have found that the production of $\Sigma$ ANs is rapid in forested regions (e.g. Day et al., 2009; Beaver et al., 2012; Fry et al., 2013; Browne et al., 2013), but the subsequent fate of these biogenic nitrates is not well constrained. During the day, $\Sigma$ ANs are produced primarily from the reaction of organic peroxy radicals $\left(\mathrm{RO}_{2}\right)$ with NO. Most of the time, this leads to the formation of $\mathrm{RO}$ and $\mathrm{NO}_{2}$ (Reaction $\mathrm{R} 2 \mathrm{a}$ ), but a fraction of the time produces an organic nitrate (Reaction $\mathrm{R} 2 \mathrm{~b}$ ). The branching ratio $k_{\mathrm{R} 2 \mathrm{~b}} /\left(k_{\mathrm{R} 2 \mathrm{~b}}+k_{\mathrm{R} 2 \mathrm{a}}\right)$ is designated $\alpha$ and varies with the structure of the $\mathrm{R}$ group, as well as the temperature and pressure.
$\mathrm{NO}+\mathrm{RO}_{2} \rightarrow \mathrm{RO}+\mathrm{NO}_{2}$

$\mathrm{NO}+\mathrm{RO}_{2}+M \rightarrow \mathrm{RONO}_{2}+M$

Organic peroxy radicals are produced in the daytime troposphere predominantly by the reaction of $\mathrm{OH}$ with VOCs and are lost through reaction with $\mathrm{NO}, \mathrm{HO}_{2}$, and $\mathrm{RO}_{2}$, or through unimolecular isomerization. These radicals reach steady state within seconds, allowing the production of $\Sigma$ ANs via Reaction (R2b) to be calculated using Eq. (3).

$P(\Sigma \mathrm{ANs})=\sum_{R_{i}} \alpha_{i} \cdot f_{\mathrm{NO}_{i}} \cdot k_{\mathrm{OH}+\mathrm{R}_{i}} \cdot\left[\mathrm{R}_{i}\right] \cdot[\mathrm{OH}]$

The value $f_{\mathrm{NO}}$ represents the fraction of $\mathrm{RO}_{2}$ radicals that are lost by reaction with NO. This value was calculated separately for each measured VOC and is equal to the rate of Reactions (R2b) and (R2a), divided by the sum of all $\mathrm{RO}_{2}$ loss rates. Rate constants for the reaction of $\mathrm{RO}_{2}$ radicals with $\mathrm{NO}, \mathrm{HO}_{2}$, and other $\mathrm{RO}_{2}$ radicals are taken from the Master Chemical Mechanism v3.2 (Saunders et al., 2003) for all species other than isoprene and methacrolein. The reactions of isoprene-derived $\mathrm{RO}_{2}$ radicals are based on the LIM-1 scheme described by Peeters et al. (2014), with the rate of unimolecular isomerization scaled to match the rate of HPALD formation observed in chamber experiments by Crounse et al. (2011). For methacrolein, we include the isomerization rate described by Crounse et al. (2012). Unimolecular isomerization is not included for any other $\mathrm{RO}_{2}$ species. Concentrations of $\mathrm{RO}_{2}$ radicals are calculated iteratively at each point until they converge.

Values of $k_{\mathrm{OH}+\mathrm{R}_{i}}$ and $\alpha_{i}$ are taken from Atkinson and Arey (2003) and Perring et al. (2013) respectively, with the following exceptions. An $\alpha$ of 0.26 is used for $\alpha$-pinene, following Rindelaub et al. (2015). An $\alpha$ of 0.12 is used for isoprene. This is in the middle of the range of branching ratios for isoprene $(0.09-0.15)$ found in recent experiments (e.g. Paulot et al., 2009; Teng et al., 2015; Xiong et al., 2015).

The missing OH reactivity (Fig. 3) is included in this calculation as a generic VOC that forms $\mathrm{RO}_{2}$ radicals that react with the same kinetics as $\mathrm{CH}_{3} \mathrm{CH}_{2} \mathrm{O}_{2}$ and has a value of $\alpha$ of 0.005 . This is an appropriate value if the missing reactivity is composed of small or highly oxygenated compounds (Perring et al., 2013). If the missing OH reactivity has a significant contribution from large hydrocarbons, then this value should be higher.

The daytime production of $\Sigma$ ANs also includes a minor contribution from the reaction of $\mathrm{NO}_{3}$ with alkenes, via Reactions (R4) and (R5).

$\mathrm{NO}_{2}+\mathrm{O}_{3} \rightarrow \mathrm{NO}_{3}+\mathrm{O}_{2}$

$\mathrm{NO}_{3}+\mathrm{R} \rightarrow \mathrm{RONO}_{2}$

Concentrations of isoprene and monoterpenes were sufficiently elevated during SOAS that the reaction with these 


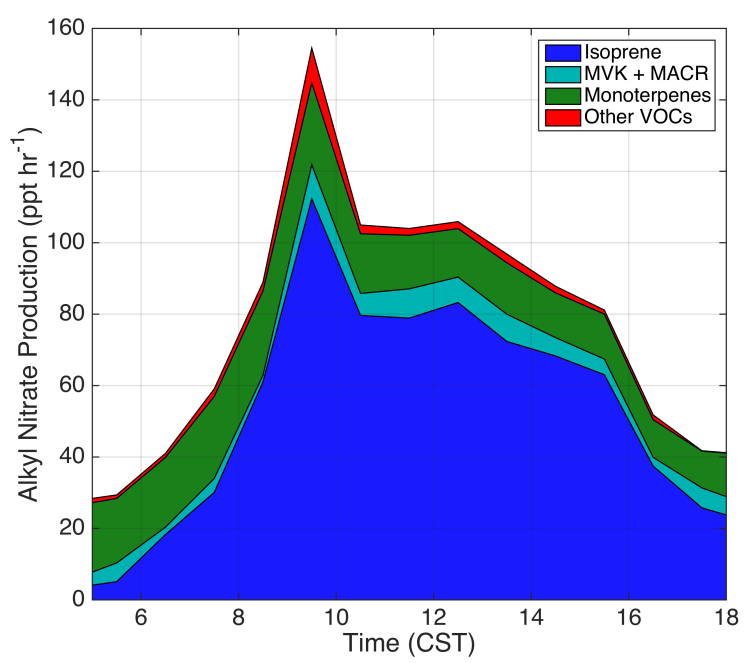

Figure 5. Average daytime production of $\Sigma$ ANs, categorized based on VOC precursors.

compounds is a significant fraction of the total daytime loss of $\mathrm{NO}_{3}$. Calculations following Ayres et al. (2015) indicate that this pathway produces $\Sigma$ ANs at an average rate of $10 \mathrm{ppth}^{-1}$.

The calculated total rate of $\Sigma$ AN production via Reactions (R2b) and (R5) is rapid, averaging approximately $90 \mathrm{ppth}^{-1}$ between 08:00 and 16:00 (Fig. 5). The oxidation of isoprene accounts for over three-quarters of the production of $\Sigma$ ANs, and monoterpenes account for an additional $15 \%$. Based on the uncertainty in each term in Eq. (3), the total systematic uncertainty in the production rate of $\Sigma$ ANs is estimated to be $\pm 55 \%$ (one sigma). The largest contribution to the total uncertainty comes from the calculation of $f_{\mathrm{NO}}$ for isoprene. Reported uncertainties for the rate constants and radical concentrations involved in $\mathrm{RO}_{2}$ loss (Boyd et al., 2003; Ghosh et al., 2010; Crounse et al., 2011; Peeters et al., 2014) combine to give an overall uncertainty of $\pm 35 \%$ in $f_{\mathrm{NO}}$ for isoprene. Uncertainty in the values of alpha and the nature of the missing OHR are also significant contributions to the total uncertainty. The effects of boundary layer growth are not accounted for, but are unlikely to be important after 10:00 (e.g. Xiong et al., 2015). The $55 \%$ uncertainty constrains the average $\Sigma$ ANs production rate to between 50 and $145 \mathrm{ppth}^{-1}$.

Rapid production of $\Sigma$ ANs decreases the $\mathrm{NO}_{x}$ lifetime only if it leads to the long-term removal of $\mathrm{NO}_{x}$ from the atmosphere. This can occur either if the alkyl and multifunctional nitrates produced are themselves long-lived, or if they have short lifetimes but are lost primarily to deposition or to conversion to a different $\mathrm{NO}_{z}$ species that is long-lived. Despite rapid production of $\Sigma$ ANs during the day, the diurnal cycle of $\Sigma$ ANs exhibits a decrease between 09:00 and 19:00 (Fig. 2c), implying that the $\Sigma$ ANs loss rate must be rapid.

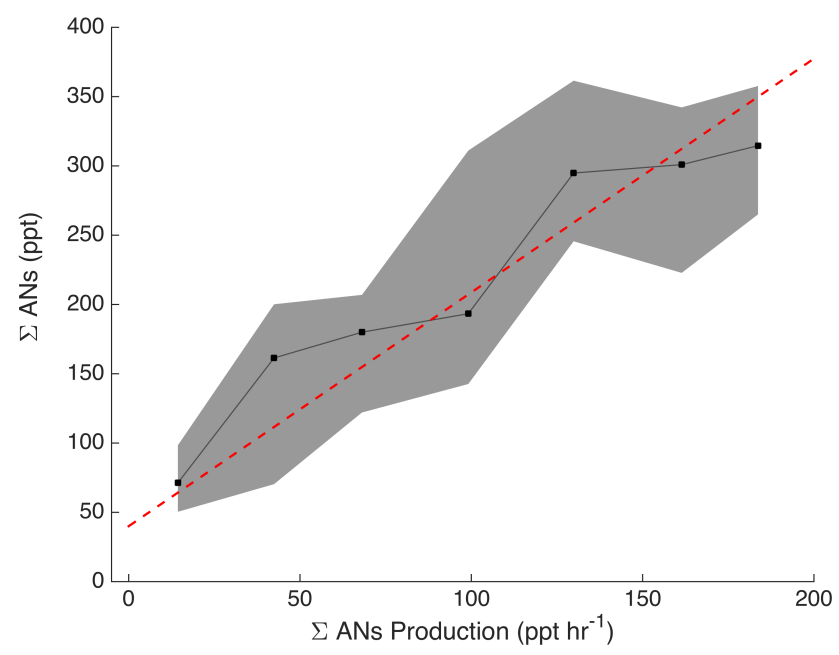

Figure 6. The concentration of $\Sigma$ ANs vs. their production rate during the afternoon (12:00-16:00). The black squares show the median in each bin, and the shaded grey area the interquartile range. A linear fit gives a slope of $1.7 \mathrm{~h}$.

While $\Sigma$ ANs do not build up over the course of a day, their concentration is strongly correlated with their instantaneous production rate in the afternoon (Fig. 6). We interpret these two results to indicate that $\Sigma$ ANs are short-lived and near steady-state in the afternoon. A least-squares fit between $\Sigma$ AN production and concentration gives a slope of $1.7 \mathrm{~h}$ and an intercept of $40 \mathrm{ppt}$. If $\Sigma$ ANs are near steadystate, then the slope of this correlation is equal to the $\Sigma \mathrm{AN}$ lifetime. The intercept of $40 \mathrm{ppt}$ is interpreted as the largescale background of long-lived $\Sigma$ ANs during summertime at mid-latitudes. This background is likely composed of small monofunctional alkyl nitrates, since these compounds typically have lifetimes of days or weeks in the summertime troposphere (e.g Clemitshaw et al., 1997). Ethyl and isopropyl nitrate were measured by GC-MS during SOAS, and show a consistent concentration of $\sim 20 \mathrm{ppt}$, explaining $50 \%$ of the intercept. Previous observations over North America suggest that the summed concentration of small monofunctional nitrates not measured during SOAS is likely also around $20 \mathrm{ppt}$ in the southeastern United States, accounting for the other $50 \%$ (e.g. Schneider et al., 1998; Blake et al., 2003; Russo et al., 2010).

A lifetime of $1.7 \mathrm{~h}$ for the reactive component of $\Sigma$ ANs is roughly consistent with previous estimates. Perring et al. (2009) found a lifetime of $1.5-2.5 \mathrm{~h}$ for $\Sigma$ ANs in the southeastern United States, based on the correlation between $\Sigma$ ANs and formaldehyde. Multiple studies have also found evidence for rapid loss of $\Sigma$ ANs through particle-phase processing in the southeastern United States (e.g. Pye et al., 2015; Lee et al., 2016). This reactive component is likely composed of larger, multifunctional nitrates that can be lost rapidly by oxidation, deposition, or hydrolysis (Lee et al., 2014; Nguyen et al., 2015; Darer et al., 2011). 
Because most $\Sigma$ ANs are short-lived, they do not serve as a permanent sink of $\mathrm{NO}_{x}$ directly. To establish whether $\Sigma$ ANs are a component of $\mathrm{NO}_{\mathrm{SL}}$ or $\mathrm{NO}_{\mathrm{LL}}$, the fate of $\Sigma$ ANs must be understood. Conversion of an alkyl nitrate to another alkyl nitrate does not affect the measurement of $\Sigma$ ANs and therefore does not contribute to the calculated $1.7 \mathrm{~h}$ lifetime. The only other $\mathrm{NO}_{y}$ compounds produced by alkyl nitrate oxidation that have been observed in laboratory experiments are $\mathrm{NO}_{x}$ and nitric acid (e.g. Lee et al., 2014; Darer et al., 2011). These two products are thought to arise from completely different mechanisms in the oxidation of $\Sigma$ ANs. $\mathrm{NO}_{x}$ is produced either during the gas-phase oxidation of nitrates (Lee et al., 2014) or by the photolysis of carbonyl nitrates (Müller et al., 2014), while nitric acid is produced only by the heterogeneous hydrolysis of hydroxy-nitrates (Darer et al., 2011). The question of whether $\Sigma \mathrm{AN}$ to nitric acid conversion is occurring is therefore equivalent to the question of whether deposition and the sum of all gas-phase loss processes are sufficient to explain the $1.7 \mathrm{~h}$ lifetime of $\Sigma$ ANs. If these processes cannot explain the short lifetime of $\Sigma$ ANs, then the unaccounted-for loss is likely due to heterogeneous formation of nitric acid.

An upper limit to the gas-phase oxidation rate of $\Sigma$ ANs can be calculated using measurements of $\Sigma$ ANs by assuming that all alkyl and multifunctional nitrates react with $\mathrm{OH}$ and $\mathrm{O}_{3}$ at the same rate as isoprene hydroxy-nitrates and that these reactions all lead to loss of $\Sigma$ ANs. Over three-quarters of the $\Sigma$ ANs produced during SOAS were isoprene hydroxynitrates (Fig. 5), making the average loss rate of $\Sigma$ ANs close to the rate for isoprene hydroxy-nitrates. In addition, under low- $\mathrm{NO}_{x}$ conditions, the most likely products of $\Sigma \mathrm{AN}$ oxidation are either $\mathrm{NO}_{x}$ or carbonyl nitrates (Lee et al., 2014). Studies by Müller et al. (2014) and Xiong et al. (2016) indicate that carbonyl nitrates are rapidly photolyzed to release $\mathrm{NO}_{x}$. If the photolysis rate is fast enough, then it is a reasonable approximation to treat $\Sigma$ ANs as releasing $\mathrm{NO}_{x}$ every time they are oxidized.

Only $\Sigma$ ANs present in the gas phase are likely to undergo deposition or reaction with $\mathrm{OH}$ or $\mathrm{O}_{3}$. Observations during SOAS indicate that $20 \%$ of $\Sigma A N$ may be in the particle phase during the afternoon (Lee et al., 2016); however, even if we assume that all $\Sigma$ ANs are gas-phase, the rate of gas-phase oxidation plus the rate of deposition measured by Nguyen et al. (2015) during SOAS is insufficient to explain the loss of $\Sigma$ ANs in the afternoon (Fig. 7, filled areas). Since isoprene hydroxy-nitrates and most other first-generation nitrates must be further oxidized before undergoing photolysis, we do not include photolysis as a separate loss process in Fig. 7. Nitrates produced in the oxidation of compounds such as MVK and MACR can undergo photolysis without reacting with $\mathrm{OH}$ first, but these are a minor fraction of the total $\Sigma$ AN production rate (Fig. 5).

If the gap between the individual loss processes and the overall loss rate of $\Sigma$ ANs is attributed entirely to $\Sigma$ AN hydrolysis, then the rate of nitric acid production from $\Sigma$ ANs

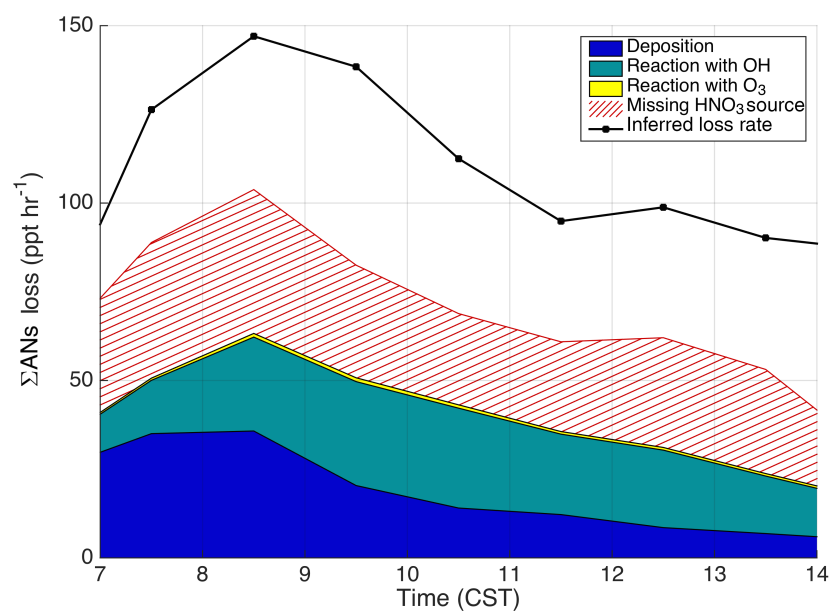

Figure 7. Loss rates and fates of $\Sigma$ ANs during SOAS. The black line shows the loss rate of $\Sigma$ ANs based on the difference between the calculated production rate and the observed change in concentration. The shaded areas show the rates of known $\Sigma$ ANs loss processes, and the hatched area shows the missing nitric acid source.

would be $65 \mathrm{ppth}^{-1}$. This is two-thirds of the total $\Sigma \mathrm{AN}$ production rate, and roughly equal to the calculated production rate of tertiary nitrates (Peeters et al., 2014; Rindelaub et al., 2015). Laboratory experiments have shown that, in general, tertiary nitrates undergo hydrolysis far faster than primary or secondary nitrates (Darer et al., 2011; Hu et al., 2011), making it likely that the rate of $\Sigma \mathrm{AN}$ hydrolysis is similar to the rate of tertiary $\Sigma$ AN production.

While the simultaneous presence of a significant missing source of nitric acid and a missing sink of $\Sigma$ ANs supports the idea that $\Sigma \mathrm{AN}$ to nitric acid conversion is occurring, the missing sink of $\Sigma$ ANs is approximately a factor of two larger than the missing source of nitric acid (Fig. 7, hatched area). The discrepancy between the two calculations of the $\Sigma$ AN hydrolysis rate could be accounted for by uncertainty in the measurements, in the calculated production rate of $\Sigma \mathrm{ANs}$, or in the calculated lifetime of nitric acid. As the data from SOAS are insufficient to determine which of these interpretations is correct, we use the average of the missing nitric acid production rate and the missing $\Sigma$ AN loss rate as our best estimate of the $\Sigma \mathrm{AN}$ hydrolysis rate.

Using this average, the rate of $\Sigma \mathrm{AN}$ hydrolysis to produce nitric acid is $45 \mathrm{ppt} \mathrm{h}^{-1}$ between 10:00 and 14:00. When this is combined with the loss of $\Sigma$ ANs by deposition, $55 \%$ of the $\Sigma$ ANs produced lead to the permanent removal of $\mathrm{NO}_{x}$ from the atmosphere. Using the hydrolysis rate calculated from only the nitric acid budget or only the $\Sigma$ ANs budget changes this fraction to 35 or $75 \%$. The remaining locally produced $\Sigma$ ANs are assumed to re-release $\mathrm{NO}_{x}$ back to the atmosphere through oxidation and photolysis.

Based on the lifetime and fate calculated here, locally produced $\Sigma$ ANs have a lifetime to re-release of $\mathrm{NO}_{x}$ of just under $4 \mathrm{~h}$, making them part of $\mathrm{NO}_{\mathrm{SL}}$. At the same time, de- 
position and the rapid conversion of reactive multifunctional nitrates to nitric acid means that the formation of $\Sigma$ ANs leads to the significant removal of $\mathrm{NO}_{\mathrm{SL}}$, and therefore $\mathrm{NO}_{x}$, from the atmosphere.

\subsection{Peroxy nitrates}

Peroxy nitrates are produced through the association of a peroxy acyl radical with $\mathrm{NO}_{2}$ (Reaction R3). While non-acyl peroxy radicals can also associate with $\mathrm{NO}_{2}$, the product is extremely unstable and decomposes within seconds in the summertime boundary layer. Peroxy nitrates are primarily lost by thermal dissociation to form $\mathrm{NO}_{2}$ and a peroxy acyl radical. This acyl radical can either react with $\mathrm{NO}_{2}$ to reform a peroxy nitrate, or react with $\mathrm{NO}$ or $\mathrm{HO}_{2}$ to form an acyloxy radical or a peracid. The lifetime of peroxy nitrates therefore depends on the temperature and the relative concentrations of $\mathrm{NO}_{2}, \mathrm{NO}$, and $\mathrm{HO}_{2}$ (LaFranchi et al., 2009). Rate constants from Orlando and Tyndall (2012) and Atkinson et al. (2006) for the reactions of peroxy acyl nitrate and acyl peroxy radical were used to calculate the lifetime of peroxy nitrates during SOAS.

During the day, peroxy nitrates re-release $\mathrm{NO}_{x}$ on timescales of $1-2 \mathrm{~h}$ and are a component of $\mathrm{NO}_{\mathrm{SL}}$. The production of peroxy nitrates therefore does not contribute to the net loss of $\mathrm{NO}_{\mathrm{SL}}$, but still affects the lifetime of $\mathrm{NO}_{\mathrm{SL}}$ by adjusting the amount of $\mathrm{NO}_{x}$ available for reactions that produce $\Sigma$ ANs or nitric acid. At SOAS, the ratio of peroxy nitrates to $\mathrm{NO}_{x}$ is typically around 0.7 at midday.

There are other loss processes of peroxy nitrates. The reaction of $\mathrm{OH}$ with methacryloyl peroxy nitrate (MPAN) is rapid, but MPAN is typically a minor component of total peroxy nitrates (LaFranchi et al., 2009). The deposition rate of peroxy nitrates was not measured during SOAS, but previous measurements in a ponderosa pine forest estimate the deposition velocity to be between 0.5 and $1.3 \mathrm{~cm} \mathrm{~s}^{-1}$ (Wolfe et al., 2009; Min et al., 2012). Using this range of deposition velocities gives a total deposition loss rate of peroxy nitrates of $5 \pm 3 \mathrm{ppth}^{-1}$ in the afternoon.

\section{The photochemical lifetime of $\mathrm{NO}_{x}$ and $\mathrm{NO}_{\mathrm{SL}}$}

The measured concentrations and calculated production and loss rates of each individual $\mathrm{NO}_{z}$ species can be combined to determine the lifetime of $\mathrm{NO}_{\mathrm{SL}}$. This lifetime depends on the distribution of $\mathrm{NO}_{z}$ between $\mathrm{NO}_{\mathrm{SL}}$ and $\mathrm{NO}_{\mathrm{LL}}$ and the chemical transformations between these two classes. If a $7 \mathrm{~h}$ lifetime to re-release of $\mathrm{NO}_{x}$ is used as the provisional dividing line between $\mathrm{NO}_{\mathrm{SL}}$ and $\mathrm{NO}_{\mathrm{LL}}$, then in the afternoon $\mathrm{NO}_{\mathrm{SL}}$ was composed of $\mathrm{NO}_{x}, \Sigma \mathrm{PNs}$, and the reactive component of $\Sigma$ ANs. As discussed earlier, both peroxy nitrates and $\Sigma$ ANs have lifetimes to re-release of $\mathrm{NO}_{x}$ of less than $4 \mathrm{~h}$. During the same time, $\mathrm{NO}_{\mathrm{LL}}$ was composed of nitric acid and unreactive $\Sigma$ ANs. We interpret the $y$ intercept in the correlation

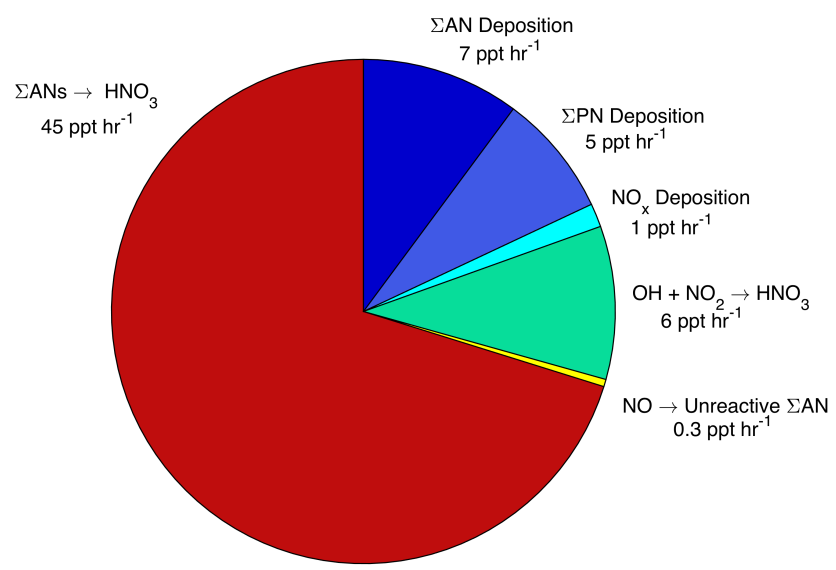

Figure 8. The average breakdown of $\mathrm{NO}_{\mathrm{SL}}$ loss between 10:00 and 14:00 during SOAS.

between $\Sigma$ AN production and concentration (Fig. 6) to represent a 40 ppt background of unreactive $\Sigma$ ANs, likely composed of small monofunctional nitrates. We treat all $\Sigma$ ANs greater than this constant background as short-lived.

The lifetime of $\mathrm{NO}_{\mathrm{SL}}$ can then be calculated as $\tau_{\mathrm{NO}}=$ $\left[\mathrm{NO}_{\mathrm{SL}}\right] / \mathcal{L}\left(\mathrm{NO}_{\mathrm{SL}}\right)$. The individual processes that lead to loss of $\mathrm{NO}_{\mathrm{SL}}$ and their average value between 10:00 and 14:00 during SOAS are shown in Fig. 8. The loss of short-lived reactive nitrogen is dominated by the hydrolysis of $\Sigma$ ANs to produce nitric acid. This single process accounts for $65 \%$ of the total $\mathrm{NO}_{\mathrm{SL}}$ loss.

$\mathrm{NO}_{\mathrm{SL}}$ is also converted to $\mathrm{NO}_{\mathrm{LL}}$ during SOAS through the association of $\mathrm{OH}$ and $\mathrm{NO}_{2}$ to produce nitric acid and the production of small, unreactive alkyl nitrates. The deposition of both peroxy nitrates and $\Sigma$ ANs, as well as the uptake of $\mathrm{NO}_{x}$ by plants, also leads to the loss of $\mathrm{NO}_{\mathrm{SL}}$. Based on the deposition velocity of $\mathrm{NO}_{x}$ over vegetation measured by Breuninger et al. (2013), the rate of $\mathrm{NO}_{x}$ uptake was calculated to be approximately $1 \mathrm{ppth}^{-1}$. A $50 \%$ uncertainty in the $\Sigma$ AN hydrolysis rate, combined in quadrature with the uncertainties from the other $\mathrm{NO}_{\mathrm{SL}}$ loss processes, gives the overall uncertainty in the $\mathrm{NO}_{\mathrm{SL}}$ loss rate of $\pm 25 \mathrm{ppth}^{-1}$.

When combined with the average concentration of $\mathrm{NO}_{\mathrm{SL}}$ of $700 \mathrm{ppt}$ during this same time period, the lifetime of $\mathrm{NO}_{\mathrm{SL}}$, and therefore the photochemical lifetime of $\mathrm{NO}_{x}$, is calculated to be $11 \pm 5 \mathrm{~h}$. This calculated lifetime of $\mathrm{NO}_{\mathrm{SL}}$ is used as the cutoff between $\mathrm{NO}_{\mathrm{SL}}$ and $\mathrm{NO}_{\mathrm{LL}}$. Changing the cutoff from our provisional value of 7 to $11 \mathrm{~h}$ does not change the partitioning of $\mathrm{NO}_{y}$ between these two classes.

The long lifetime of $\mathrm{NO}_{x}$ calculated here is qualitatively consistent with the partitioning of $\mathrm{NO}_{y}$ during SOAS. The concentration of $\mathrm{NO}_{\mathrm{SL}}$ is approximately twice as large as $\mathrm{NO}_{\text {LL }}$ during the afternoon (Fig. 2). In the absence of large fresh emissions of $\mathrm{NO}_{x}$, this implies that the conversion of $\mathrm{NO}_{\mathrm{SL}}$ to $\mathrm{NO}_{\mathrm{LL}}$ must be slow, in agreement with our calculations. More quantitative calculations of the $\mathrm{NO}_{x}$ lifetime 
using the ratio of $\mathrm{NO}_{\mathrm{SL}}$ to $\mathrm{NO}_{\mathrm{LL}}$ or $\mathrm{NO}_{x}$ to $\mathrm{NO}_{y}$ have been developed for analyses of plumes (e.g. Kleinman et al., 2000; Ryerson et al., 2003) but are not adaptable to this data set.

This $\mathrm{NO}_{x}$ lifetime is longer than the lifetime of $\mathrm{NO}_{x}$ calculated in fresh plumes, where observational studies have found lifetimes of 5-8 h (e.g. Ryerson et al., 1998; Alvarado et al., 2010; Valin et al., 2013). These studies focus solely on the chemistry of $\mathrm{NO}_{x}$ rather than $\mathrm{NO}_{\mathrm{SL}}$ and recognition of the buffering effect of organic nitrates would extend the lifetimes found in these studies. In addition, the average noontime concentration of $\mathrm{OH}$ observed during SOAS was up to a factor of 5 lower than values typically observed in urban areas (e.g. Mao et al., 2010; Rohrer et al., 2014). Lower concentrations of $\mathrm{OH}$ slow the rate of atmospheric oxidation, leading to longer lifetimes of $\mathrm{NO}_{x}$.

If lower $\mathrm{OH}$ and the production of $\mathrm{NO}_{x}$ from peroxy nitrates were the only differences between polluted areas and the regional background, then the lifetime of $\mathrm{NO}_{x}$ during SOAS would be significantly longer than $10 \mathrm{~h}$. However, the production of $\Sigma$ ANs is extremely rapid and the deposition and hydrolysis of these species accounts for the majority of the $\mathrm{NO}_{x}$ removal in this rural region. The VOC mixture present in the southeastern United States leads to very high values of $\mathrm{OH}$ reactivity and $\alpha$, both of which enhance the production of $\Sigma$ ANs. High concentrations of VOCs also lead to lower $\mathrm{OH}$ concentrations and slower production of nitric acid by Reaction (R1). Moving from urban centers to rural or remote regions is therefore also a move from nitric acidto $\Sigma$ AN-dominated $\mathrm{NO}_{x}$ chemistry. Changes to our understanding of the production and fate of alkyl and multifunctional nitrates will therefore have a large impact on predictions of the lifetime of $\mathrm{NO}_{x}$ and $\mathrm{NO}_{\mathrm{SL}}$, with subsequent impacts on the concentration and distribution of $\mathrm{NO}_{x}$ across a region.

\section{Conclusions}

Measurements in a low- $\mathrm{NO}_{x}$, high-VOC region provide new insights into the lifetime and chemistry of $\mathrm{NO}_{x}$ and $\mathrm{NO}_{\mathrm{SL}}$ in rural areas. $\mathrm{NO}_{\mathrm{SL}}$ is found to have an average lifetime of $11 \pm 5 \mathrm{~h}$, longer than the lifetimes of $\mathrm{NO}_{x}$ observed in plume studies, which do not account for buffering by short-lived $\mathrm{NO}_{z}$ species. The long lifetime of $\mathrm{NO}_{\mathrm{SL}}$ makes it relatively evenly distributed across the region and allows small inputs of $\mathrm{NO}_{x}$ to sustain the concentrations of $\mathrm{NO}_{\mathrm{SL}}$ observed during SOAS.

The long daytime lifetime of $\mathrm{NO}_{\mathrm{SL}}$ found here indicates that $\mathrm{NO}_{x}$ emitted on one day will persist into the night where $\mathrm{NO}_{3}$ is often the most important oxidant (Brown and Stutz, 2012). Depending on the chemistry taking place, $\mathrm{NO}_{\mathrm{SL}}$ could either be efficiently removed from the atmosphere at night, or remain in the atmosphere until the next day. To fully understand the transport and distribution of $\mathrm{NO}_{x}$ across a region the daytime chemistry of $\mathrm{NO}_{x}$ discussed here must be com- bined with additional analyses of the nighttime chemistry of $\mathrm{NO}_{x}$ and $\mathrm{NO}_{y}$ (e.g. Brown et al., 2009; Crowley et al., 2011; Ayres et al., 2015).

The production and loss of $\Sigma$ ANs are found to be the most important variables in controlling the lifetime of $\mathrm{NO}_{\mathrm{SL}}$. $\Sigma$ ANs were observed to have a lifetime of under $2 \mathrm{~h}$ during the afternoon. This estimate is in line with many previous estimates of $\Sigma$ AN lifetimes, and indicates that $\Sigma$ ANs are an important short-lived $\mathrm{NO}_{x}$ reservoir. Observations of both nitric acid and $\Sigma$ ANs during SOAS provide strong evidence that both gas-phase oxidation to produce $\mathrm{NO}_{x}$ and particle-phase hydrolysis to produce nitric acid are important chemical loss processes for $\Sigma$ ANs. Comparison of the nitric acid and $\Sigma$ AN budgets indicate that between 30 and $70 \%$ of the alkyl and multifunctional nitrates produced are converted to nitric acid. Further laboratory and field studies are necessary to better constrain this percentage and to understand the mechanisms that control it.

The vast majority of these $\Sigma$ ANs are formed during the oxidation of biogenic hydrocarbons, while much of the $\mathrm{NO}_{x}$ is emitted by anthropogenic activities. In this way, the formation of $\Sigma$ ANs represents an important anthropogenicbiogenic interaction, where the oxidation of biogenic VOCs serves to remove anthropogenic pollution from the atmosphere. In rural and remote regions, the interactions between $\mathrm{NO}_{y}, \mathrm{HO}_{\mathrm{x}}$, and VOCs are complex and bi-directional. As $\mathrm{NO}_{x}$ emissions decrease, $\Sigma$ ANs will likely become an even more important part of the $\mathrm{NO}_{y}$ budget, making it increasingly important that their chemistry and loss be taken into consideration when calculating the lifetime and fate of $\mathrm{NO}_{x}$.

Acknowledgements. Financial and logistical support for SOAS was provided by the NSF, the Earth Observing Laboratory at the National Center for Atmospheric Research (operated by NSF), the personnel at Atmospheric Research and Analysis, and the Electric Power Research Institute. The Berkeley authors acknowledge the support of the NOAA Office of Global Programs (NA13OAR4310067) and the NSF (AGS-1352972) and by EPA STAR Grant 835407 (to Allen H. Goldstein). The Caltech authors acknowledge the support of the NSF (AGS-1331360, AGS-1240604). The Penn State authors acknowledge the support of the NSF (AGS-1246918). Ronald C. Cohen acknowledges support from the Miller Institute for Basic Research.

Edited by: D. Heard

\section{References}

Allen, H. M., Draper, D. C., Ayres, B. R., Ault, A., Bondy, A., Takahama, S., Modini, R. L., Baumann, K., Edgerton, E., Knote, C., Laskin, A., Wang, B., and Fry, J. L.: Influence of crustal dust and sea spray supermicron particle concentrations and acidity on inorganic $\mathrm{NO}_{3}^{-}$aerosol during the 2013 Southern Oxidant and Aerosol Study, Atmos. Chem. Phys., 15, 10669-10685, doi:10.5194/acp-15-10669-2015, 2015. 
Alvarado, M. J., Logan, J. A., Mao, J., Apel, E., Riemer, D., Blake, D., Cohen, R. C., Min, K.-E., Perring, A. E., Browne, E. C., Wooldridge, P. J., Diskin, G. S., Sachse, G. W., Fuelberg, H., Sessions, W. R., Harrigan, D. L., Huey, G., Liao, J., Case-Hanks, A., Jimenez, J. L., Cubison, M. J., Vay, S. A., Weinheimer, A. J., Knapp, D. J., Montzka, D. D., Flocke, F. M., Pollack, I. B., Wennberg, P. O., Kurten, A., Crounse, J., St. Clair, J. M., Wisthaler, A., Mikoviny, T., Yantosca, R. M., Carouge, C. C., and Le Sager, P.: Nitrogen oxides and PAN in plumes from boreal fires during ARCTAS-B and their impact on ozone: an integrated analysis of aircraft and satellite observations, Atmos. Chem. Phys., 10, 9739-9760, doi:10.5194/acp-10-9739-2010, 2010.

Atkinson, R. and Arey, J.: Atmospheric Degradation of Volatile Organic Compounds, Chem. Rev., 103, 4605-4638, doi:10.1021/cr0206420, 2003.

Atkinson, R., Baulch, D. L., Cox, R. A., Crowley, J. N., Hampson, R. F., Hynes, R. G., Jenkin, M. E., Rossi, M. J., Troe, J., and IUPAC Subcommittee: Evaluated kinetic and photochemical data for atmospheric chemistry: Volume II - gas phase reactions of organic species, Atmos. Chem. Phys., 6, 3625-4055, doi:10.5194/acp-6-3625-2006, 2006.

Ayres, B. R., Allen, H. M., Draper, D. C., Brown, S. S., Wild, R. J., Jimenez, J. L., Day, D. A., Campuzano-Jost, P., Hu, W., de Gouw, J., Koss, A., Cohen, R. C., Duffey, K. C., Romer, P., Baumann, K., Edgerton, E., Takahama, S., Thornton, J. A., Lee, B. H., Lopez-Hilfiker, F. D., Mohr, C., Wennberg, P. O., Nguyen, T. B., Teng, A., Goldstein, A. H., Olson, K., and Fry, J. L.: Organic nitrate aerosol formation via $\mathrm{NO}_{3}+$ biogenic volatile organic compounds in the southeastern United States, Atmos. Chem. Phys., 15, 13377-13392, doi:10.5194/acp-15-13377-2015, 2015.

Beaver, M. R., St. Clair, J. M., Paulot, F., Spencer, K. M., Crounse, J. D., LaFranchi, B. W., Min, K. E., Pusede, S. E., Wooldridge, P. J., Schade, G. W., Park, C., Cohen, R. C., and Wennberg, P. O.: Importance of biogenic precursors to the budget of organic nitrates: observations of multifunctional organic nitrates by CIMS and TD-LIF during BEARPEX 2009, Atmos. Chem. Phys., 12, 5773-5785, doi:10.5194/acp-12-5773-2012, 2012.

Blake, N. J., Blake, D. R., Sive, B. C., Katzenstein, A. S., Meinardi, S., Wingenter, O. W., Atlas, E. L., Flocke, F., Ridley, B. A., and Rowland, F. S.: The seasonal evolution of NMHCs and light alkyl nitrates at middle to high northern latitudes during TOPSE, J. Geophys. Res., 108, 8359, doi:10.1029/2001JD001467, 2003.

Boyd, A. A., Flaud, P.-M., Daugey, N., and Lesclaux, R.: Rate Constants for $\mathrm{RO}_{2}+\mathrm{HO}_{2}$ Reactions Measured under a Large Excess of $\mathrm{HO}_{2}$, J. Phys. Chem. A, 107, 818-821, doi:10.1021/jp026581r, 2003.

Breuninger, C., Meixner, F. X., and Kesselmeier, J.: Field investigations of nitrogen dioxide $\left(\mathrm{NO}_{2}\right)$ exchange between plants and the atmosphere, Atmos. Chem. Phys., 13, 773-790, doi:10.5194/acp-13-773-2013, 2013.

Brown, S. S. and Stutz, J.: Nighttime radical observations and chemistry, Chem. Soc. Rev., 41, 6405-6447, doi:10.1039/C2CS35181A, 2012.

Brown, S. S., Dubé, W. P., Fuchs, H., Ryerson, T. B., Wollny, A. G., Brock, C. A., Bahreini, R., Middlebrook, A. M., Neuman, J. A., Atlas, E., Roberts, J. M., Osthoff, H. D., Trainer, M., Fehsenfeld, F. C., and Ravishankara, A. R.: Reactive uptake coefficients for $\mathrm{N}_{2} \mathrm{O}_{5}$ determined from aircraft measurements during the Second Texas Air Quality Study: Comparison to cur- rent model parameterizations, J. Geophys. Res., 114, D00F10, doi:10.1029/2008JD011679, 2009.

Browne, E. C. and Cohen, R. C.: Effects of biogenic nitrate chemistry on the $\mathrm{NO}_{x}$ lifetime in remote continental regions, Atmos. Chem. Phys., 12, 11917-11932, doi:10.5194/acp-1211917-2012, 2012.

Browne, E. C., Min, K.-E., Wooldridge, P. J., Apel, E., Blake, D. R., Brune, W. H., Cantrell, C. A., Cubison, M. J., Diskin, G. S., Jimenez, J. L., Weinheimer, A. J., Wennberg, P. O., Wisthaler, A., and Cohen, R. C.: Observations of total $\mathrm{RONO}_{2}$ over the boreal forest: $\mathrm{NO}_{x}$ sinks and $\mathrm{HNO}_{3}$ sources, Atmos. Chem. Phys., 13, 4543-4562, doi:10.5194/acp-13-4543-2013, 2013.

Burkholder, J. B., Talukdar, R. K., Ravishankara, A. R., and Solomon, S.: Temperature dependence of the $\mathrm{HNO}_{3}$ UV absorption cross sections, J. Geophys. Res.-Atmos., 98, 22937-22948, doi:10.1029/93JD02178, 1993.

Clemitshaw, K. C., Williams, J., Rattigan, O. V., Shallcross, D. E., Law, K. S., and Cox, R. A.: Gas-phase ultraviolet absorption cross-sections and atmospheric lifetimes of several $\mathrm{C}_{2}-$ $\mathrm{C}_{5}$ alkyl nitrates, J. Photochem. Photobio. A, 102, 117-126, doi:10.1016/S1010-6030(96)04458-9, 1997.

Crounse, J. D., McKinney, K. A., Kwan, A. J., and Wennberg, P. O.: Measurement of Gas-Phase Hydroperoxides by Chemical Ionization Mass Spectrometry, Anal. Chem., 78, 6726-6732, doi:10.1021/ac0604235, 2006.

Crounse, J. D., Paulot, F., Kjaergaard, H. G., and Wennberg, P. O.: Peroxy radical isomerization in the oxidation of isoprene, Phys. Chem. Chem. Phys., 13, 13607-13613, doi:10.1039/C1CP21330J, 2011.

Crounse, J. D., Knap, H. C., Ørnsø, K. B., Jørgensen, S., Paulot, F., Kjaergaard, H. G., and Wennberg, P. O.: Atmospheric Fate of Methacrolein. 1. Peroxy Radical Isomerization Following Addition of $\mathrm{OH}$ and $\mathrm{O}_{2}$, J. Phys. Chem. A, 116, 5756-5762, doi:10.1021/jp211560u, 2012.

Crowley, J. N., Thieser, J., Tang, M. J., Schuster, G., Bozem, H., Beygi, Z. H., Fischer, H., Diesch, J.-M., Drewnick, F., Borrmann, S., Song, W., Yassaa, N., Williams, J., Pöhler, D., Platt, U., and Lelieveld, J.: Variable lifetimes and loss mechanisms for $\mathrm{NO}_{3}$ and $\mathrm{N}_{2} \mathrm{O}_{5}$ during the DOMINO campaign: contrasts between marine, urban and continental air, Atmos. Chem. Phys., 11, 10853-10870, doi:10.5194/acp-11-10853-2011, 2011.

Curier, R., Kranenburg, R., Segers, A., Timmermans, R., and Schaap, M.: Synergistic use of OMI $\mathrm{NO}_{2}$ tropospheric columns and LOTOS-EUROS to evaluate the $\mathrm{NO}_{x}$ emission trends across Europe, Remote Sens. Environ., 149, 58-69, doi:10.1016/j.rse.2014.03.032, 2014

Dallmann, T. R. and Harley, R. A.: Evaluation of mobile source emission trends in the United States, J. Geophys. Res., 115, D14305, doi:10.1029/2010JD013862, 2010.

Darer, A. I., Cole-Filipiak, N. C., O'Connor, A. E., and Elrod, M. J.: Formation and Stability of Atmospherically Relevant IsopreneDerived Organosulfates and Organonitrates, Environ. Sci. Technol., 45, 1895-1902, doi:10.1021/es103797z, 2011.

Day, D. A., Wooldridge, P. J., Dillon, M. B., Thornton, J. A., and Cohen, R. C.: A thermal dissociation laser-induced fluorescence instrument for in situ detection of $\mathrm{NO}_{2}$, peroxy nitrates, alkyl nitrates, and $\mathrm{HNO}_{3}$, J. Geophys. Res., 107, 4046, doi:10.1029/2001JD000779, 2002. 
Day, D. A., Dillon, M. B., Wooldridge, P. J., Thornton, J. A., Rosen, R. S., Wood, E. C., and Cohen, R. C.: On alkyl nitrates, $\mathrm{O}_{3}$, and the "missing $\mathrm{NO}_{y}$ ", J. Geophys. Res., 108, 4501, doi:10.1029/2003JD003685, 2003.

Day, D. A., Farmer, D. K., Goldstein, A. H., Wooldridge, P. J., Minejima, C., and Cohen, R. C.: Observations of $\mathrm{NO}_{x}, \Sigma \mathrm{PNs}$, $\Sigma$ ANs, and $\mathrm{HNO}_{3}$ at a Rural Site in the California Sierra Nevada Mountains: summertime diurnal cycles, Atmos. Chem. Phys., 9, 4879-4896, doi:10.5194/acp-9-4879-2009, 2009.

Di Carlo, P., Brune, W. H., Martinez, M., Harder, H., Lesher, R., Ren, X., Thornberry, T., Carroll, M. A., Young, V., Shepson, P. B., Riemer, D., Apel, E., and Campbell, C.: Missing OH Reactivity in a Forest: Evidence for Unknown Reactive Biogenic VOCs, Science, 304, 722-725, doi:10.1126/science.1094392, 2004.

Dillon, M. B., Lamanna, M. S., Schade, G. W., Goldstein, A. H., and Cohen, R. C.: Chemical evolution of the Sacramento urban plume: Transport and oxidation, J. Geophys. Res.-Atmos., 107, 4045, doi:10.1029/2001JD000969, 2002.

Faloona, I. C., Tan, D., Lesher, R. L., Hazen, N. L., Frame, C. L., Simpas, J. B., Harder, H., Martinez, M., Di Carlo, P., Ren, X., and Brune, W. H.: A Laser-induced Fluorescence Instrument for Detecting Tropospheric $\mathrm{OH}$ and $\mathrm{HO}_{2}$ : Characteristics and Calibration, J. Atmos. Chem., 47, 139-167, doi:10.1023/B:JOCH.0000021036.53185.0e, 2004.

Finlayson-Pitts, B. and Pitts, J.: Chemistry of the Upper and Lower Atmosphere: Theory, Experiments, and Applications, Elsevier Science, San Diego, 1999.

Fowler, D., Coyle, M., Skiba, U., Sutton, M. A., Cape, J. N., Reis, S., Sheppard, L. J., Jenkins, A., Grizzetti, B., Galloway, J. N., Vitousek, P., Leach, A., Bouwman, A. F., Butterbach-Bahl, K., Dentener, F., Stevenson, D., Amann, M., and Voss, M.: The global nitrogen cycle in the twenty-first century, Philos. T. Roy. Soc. B, 368, doi:10.1098/rstb.2013.0164, 2013.

Fry, J. L., Draper, D. C., Zarzana, K. J., Campuzano-Jost, P., Day, D. A., Jimenez, J. L., Brown, S. S., Cohen, R. C., Kaser, L., Hansel, A., Cappellin, L., Karl, T., Hodzic Roux, A., Turnipseed, A., Cantrell, C., Lefer, B. L., and Grossberg, N.: Observations of gas- and aerosol-phase organic nitrates at BEACHON-RoMBAS 2011, Atmos. Chem. Phys., 13, 8585-8605, doi:10.5194/acp-138585-2013, 2013.

Fuchs, H., Bohn, B., Hofzumahaus, A., Holland, F., Lu, K. D., Nehr, S., Rohrer, F., and Wahner, A.: Detection of $\mathrm{HO}_{2}$ by laserinduced fluorescence: calibration and interferences from $\mathrm{RO}_{2}$ radicals, Atmos. Meas. Tech., 4, 1209-1225, doi:10.5194/amt4-1209-2011, 2011.

Fuentes, J. D., Wang, D., Bowling, D. R., Potosnak, M., Monson, R. K., Goliff, W. S., and Stockwell, W. R.: Biogenic Hydrocarbon Chemistry within and Above a Mixed Deciduous Forest, J. Atmos. Chem., 56, 165-185, doi:10.1007/s10874-006-9048-4, 2007.

Ghosh, B., Bugarin, A., Connell, B. T., and North, S. W.: IsomerSelective Study of the OH-Initiated Oxidation of Isoprene in the Presence of $\mathrm{O}_{2}$ and NO: 2. The Major OH Addition Channel, J. Phys. Chem. A, 114, 2553-2560, doi:10.1021/jp909052t, 2010.

Gilman, J. B., Burkhart, J. F., Lerner, B. M., Williams, E. J., Kuster, W. C., Goldan, P. D., Murphy, P. C., Warneke, C., Fowler, C., Montzka, S. A., Miller, B. R., Miller, L., Oltmans, S. J., Ryerson, T. B., Cooper, O. R., Stohl, A., and de Gouw, J. A.:
Ozone variability and halogen oxidation within the Arctic and sub-Arctic springtime boundary layer, Atmos. Chem. Phys., 10, 10223-10236, doi:10.5194/acp-10-10223-2010, 2010.

Goldan, P. D., Kuster, W. C., Williams, E., Murphy, P. C., Fehsenfeld, F. C., and Meagher, J.: Nonmethane hydrocarbon and oxy hydrocarbon measurements during the 2002 New England Air Quality Study, J. Geophys. Res., 109, D21309, doi:10.1029/2003JD004455, 2004.

Goldstein, A. H. and Galbally, I. E.: Known and Unexplored Organic Constituents in the Earth's Atmosphere, Environ. Sci. Technol., 41, 1514-1521, doi:10.1021/es072476p, 2007.

Hansen, D. A., Edgerton, E. S., Hartsell, B. E., Jansen, J. J., Kandasamy, N., Hidy, G. M., and Blanchard, C. L.: The Southeastern Aerosol Research and Characterization Study: Part 1 - Overview, J. Air Waste Manage., 53, 1460-1471, doi:10.1080/10473289.2003.10466318, 2003.

Hennigan, C. J., Sullivan, A. P., Fountoukis, C. I., Nenes, A., Hecobian, A., Vargas, O., Peltier, R. E., Case Hanks, A. T., Huey, L. G., Lefer, B. L., Russell, A. G., and Weber, R. J.: On the volatility and production mechanisms of newly formed nitrate and water soluble organic aerosol in Mexico City, Atmos. Chem. Phys., 8, 3761-3768, doi:10.5194/acp-8-3761-2008, 2008.

Hidy, G. M., Blanchard, C. L., Baumann, K., Edgerton, E., Tanenbaum, S., Shaw, S., Knipping, E., Tombach, I., Jansen, J., and Walters, J.: Chemical climatology of the southeastern United States, 1999-2013, Atmos. Chem. Phys., 14, 11893-11914, doi:10.5194/acp-14-11893-2014, 2014.

Hu, K. S., Darer, A. I., and Elrod, M. J.: Thermodynamics and kinetics of the hydrolysis of atmospherically relevant organonitrates and organosulfates, Atmos. Chem. Phys., 11, 8307-8320, doi:10.5194/acp-11-8307-2011, 2011.

Hudman, R. C., Moore, N. E., Mebust, A. K., Martin, R. V., Russell, A. R., Valin, L. C., and Cohen, R. C.: Steps towards a mechanistic model of global soil nitric oxide emissions: implementation and space based-constraints, Atmos. Chem. Phys., 12, 7779-7795, doi:10.5194/acp-12-7779-2012, 2012.

Ito, A., Sillman, S., and Penner, J. E.: Effects of additional nonmethane volatile organic compounds, organic nitrates, and direct emissions of oxygenated organic species on global tropospheric chemistry, J. Geophys. Res.-Atmos., 112, D06309, doi:10.1029/2005JD006556, 2007.

Kaiser, J., Skog, K. M., Baumann, K., Bertman, S. B., Brown, S. B., Brune, W. H., Crounse, J. D., de Gouw, J. A., Edgerton, E. S., Feiner, P. A., Goldstein, A. H., Koss, A., Misztal, P. K., Nguyen, T. B., Olson, K. F., St. Clair, J. M., Teng, A. P., Toma, S., Wennberg, P. O., Wild, R. J., Zhang, L., and Keutsch, F. N.: Speciation of $\mathrm{OH}$ reactivity above the canopy of an isoprene-dominated forest, Atmos. Chem. Phys. Discuss., doi:10.5194/acp-2015-1006, in review, 2016.

Kaser, L., Karl, T., Schnitzhofer, R., Graus, M., Herdlinger-Blatt, I. S., DiGangi, J. P., Sive, B., Turnipseed, A., Hornbrook, R. S., Zheng, W., Flocke, F. M., Guenther, A., Keutsch, F. N., Apel, E., and Hansel, A.: Comparison of different real time VOC measurement techniques in a ponderosa pine forest, Atmos. Chem. Phys., 13, 2893-2906, doi:10.5194/acp-13-2893-2013, 2013.

Kleinman, L. I., Daum, P. H., Imre, D. G., Lee, J. H., Lee, Y.-N., Nunnermacker, L. J., Springston, S. R., WeinsteinLloyd, J., and Newman, L.: Ozone production in the New 
York City urban plume, J. Geophys. Res., 105, 14495-14511, doi:10.1029/2000JD900011, 2000.

LaFranchi, B. W., Wolfe, G. M., Thornton, J. A., Harrold, S. A., Browne, E. C., Min, K. E., Wooldridge, P. J., Gilman, J. B., Kuster, W. C., Goldan, P. D., de Gouw, J. A., McKay, M., Goldstein, A. H., Ren, X., Mao, J., and Cohen, R. C.: Closing the peroxy acetyl nitrate budget: observations of acyl peroxy nitrates (PAN, PPN, and MPAN) during BEARPEX 2007, Atmos. Chem. Phys., 9, 7623-7641, doi:10.5194/acp-9-7623-2009, 2009.

Lee, B. H., Mohr, C., Lopez-Hilfiker, F. D., Lutz, A., Hallquist, M., Lee, L., Romer, P., Cohen, R. C., Iyer, S., Kurtén, T., Hu, W., Day, D. A., Campuzano-Jost, P., Jimenez, J. L., Xu, L., Ng, N. L., Guo, H., Weber, R. J., Wild, R. J., Brown, S. S., Koss, A., de Gouw, J., Olson, K., Goldstein, A. H., Seco, R., Kim, S., McAvey, K., Shepson, P. B., Starn, T., Baumann, K., Edgerton, E. S., Liu, J., Shilling, J. E., Miller, D. O., Brune, W., Schobesberger, S., D'Ambro, E. L., and Thornton, J. A.: Highly functionalized organic nitrates in the southeast United States: Contribution to secondary organic aerosol and reactive nitrogen budgets, P. Natl. Acad. Sci. USA, 113, 1516-1521, doi:10.1073/pnas.1508108113, 2016.

Lee, L., Teng, A. P., Wennberg, P. O., Crounse, J. D., and Cohen, R. C.: On Rates and Mechanisms of $\mathrm{OH}$ and $\mathrm{O}_{3}$ Reactions with Isoprene-Derived Hydroxy Nitrates, J. Phys. Chem. A, 118, 1622-1637, doi:10.1021/jp4107603, 2014.

Liu, S., Shilling, J. E., Song, C., Hiranuma, N., Zaveri, R. A., and Russell, L. M.: Hydrolysis of Organonitrate Functional Groups in Aerosol Particles, Aerosol Sci. Tech., 46, 1359-1369, doi:10.1080/02786826.2012.716175, 2012.

Mao, J., Ren, X., Brune, W. H., Olson, J. R., Crawford, J. H., Fried, A., Huey, L. G., Cohen, R. C., Heikes, B., Singh, H. B., Blake, D. R., Sachse, G. W., Diskin, G. S., Hall, S. R., and Shetter, R. E.: Airborne measurement of $\mathrm{OH}$ reactivity during INTEX-B, Atmos. Chem. Phys., 9, 163-173, doi:10.5194/acp-9-163-2009, 2009.

Mao, J., Ren, X., Chen, S., Brune, W. H., Chen, Z., Martinez, M., Harder, H., Lefer, B., Rappenglück, B., Flynn, J., and Leuchner, M.: Atmospheric oxidation capacity in the summer of Houston 2006: Comparison with summer measurements in other metropolitan studies, Atmos. Environ., 44, 4107-4115, doi:10.1016/j.atmosenv.2009.01.013, 2010.

Mao, J., Ren, X., Zhang, L., Van Duin, D. M., Cohen, R. C., Park, J.-H., Goldstein, A. H., Paulot, F., Beaver, M. R., Crounse, J. D., Wennberg, P. O., DiGangi, J. P., Henry, S. B., Keutsch, F. N., Park, C., Schade, G. W., Wolfe, G. M., Thornton, J. A., and Brune, W. H.: Insights into hydroxyl measurements and atmospheric oxidation in a California forest, Atmos. Chem. Phys., 12, 8009-8020, doi:10.5194/acp-12-8009-2012, 2012.

Mao, J., Paulot, F., Jacob, D. J., Cohen, R. C., Crounse, J. D., Wennberg, P. O., Keller, C. A., Hudman, R. C., Barkley, M. P., and Horowitz, L. W.: Ozone and organic nitrates over the eastern United States: Sensitivity to isoprene chemistry, J. Geophys. Res.-Atmos., 118, 11256-11268, doi:10.1002/jgrd.50817, 2013.

Martinez, M., Harder, H., Kovacs, T. A., Simpas, J. B., Bassis, J., Lesher, R., Brune, W. H., Frost, G. J., Williams, E. J., Stroud, C. A., Jobson, B. T., Roberts, J. M., Hall, S. R., Shetter, R. E., Wert, B., Fried, A., Alicke, B., Stutz, J., Young, V. L., White, A. B., and Zamora, R. J.: $\mathrm{OH}$ and $\mathrm{HO}_{2}$ concentrations, sources, and loss rates during the Southern Oxidants Study in Nashville, Tennessee, summer 1999, J. Geophys. Res., 108, 4617, doi:10.1029/2003JD003551, 2003.

Mebust, A. K. and Cohen, R. C.: Space-based observations of fire $\mathrm{NO}_{x}$ emission coefficients: a global biome-scale comparison, Atmos. Chem. Phys., 14, 2509-2524, doi:10.5194/acp-14-25092014, 2014.

Millet, D. B., Baasandorj, M., Farmer, D. K., Thornton, J. A., Baumann, K., Brophy, P., Chaliyakunnel, S., de Gouw, J. A., Graus, M., Hu, L., Koss, A., Lee, B. H., Lopez-Hilfiker, F. D., Neuman, J. A., Paulot, F., Peischl, J., Pollack, I. B., Ryerson, T. B., Warneke, C., Williams, B. J., and Xu, J.: A large and ubiquitous source of atmospheric formic acid, Atmos. Chem. Phys., 15, 6283-6304, doi:10.5194/acp-15-6283-2015, 2015.

Min, K.-E., Pusede, S. E., Browne, E. C., LaFranchi, B. W., Wooldridge, P. J., Wolfe, G. M., Harrold, S. A., Thornton, J. A., and Cohen, R. C.: Observations of atmosphere-biosphere exchange of total and speciated peroxynitrates: nitrogen fluxes and biogenic sources of peroxynitrates, Atmos. Chem. Phys., 12, 9763-9773, doi:10.5194/acp-12-9763-2012, 2012.

Min, K.-E., Pusede, S. E., Browne, E. C., LaFranchi, B. W., and Cohen, R. C.: Eddy covariance fluxes and vertical concentration gradient measurements of $\mathrm{NO}$ and $\mathrm{NO}_{2}$ over a ponderosa pine ecosystem: observational evidence for within-canopy chemical removal of $\mathrm{NO}_{x}$, Atmos. Chem. Phys., 14, 5495-5512, doi:10.5194/acp-14-5495-2014, 2014.

Mogensen, D., Gierens, R., Crowley, J. N., Keronen, P., Smolander, S., Sogachev, A., Nölscher, A. C., Zhou, L., Kulmala, M., Tang, M. J., Williams, J., and Boy, M.: Simulations of atmospheric $\mathrm{OH}, \mathrm{O}_{3}$ and $\mathrm{NO}_{3}$ reactivities within and above the boreal forest, Atmos. Chem. Phys., 15, 3909-3932, doi:10.5194/acp-15-39092015, 2015.

Mollner, A. K., Valluvadasan, S., Feng, L., Sprague, M. K., Okumura, M., Milligan, D. B., Bloss, W. J., Sander, S. P., Martien, P. T., Harley, R. A., McCoy, A. B., and Carter, W. P. L.: Rate of Gas Phase Association of Hydroxyl Radical and Nitrogen Dioxide, Science, 330, 646-649, doi:10.1126/science.1193030, 2010.

Müller, J.-F., Peeters, J., and Stavrakou, T.: Fast photolysis of carbonyl nitrates from isoprene, Atmos. Chem. Phys., 14, $2497-$ 2508, doi:10.5194/acp-14-2497-2014, 2014.

Nguyen, T. B., Crounse, J. D., Teng, A. P., St. Clair, J. M., Paulot, F., Wolfe, G. M., and Wennberg, P. O.: Rapid deposition of oxidized biogenic compounds to a temperate forest, P. Natl. Acad. Sci. USA, 112, E392-E401, doi:10.1073/pnas.1418702112, 2015.

Orlando, J. J. and Tyndall, G. S.: Laboratory studies of organic peroxy radical chemistry: an overview with emphasis on recent issues of atmospheric significance, Chem. Soc. Rev., 41, 62946317, doi:10.1039/c2cs35166h, 2012.

Papale, D., Reichstein, M., Aubinet, M., Canfora, E., Bernhofer, C., Kutsch, W., Longdoz, B., Rambal, S., Valentini, R., Vesala, T., and Yakir, D.: Towards a standardized processing of Net Ecosystem Exchange measured with eddy covariance technique: algorithms and uncertainty estimation, Biogeosciences, 3, 571-583, doi:10.5194/bg-3-571-2006, 2006.

Paulot, F., Crounse, J. D., Kjaergaard, H. G., Kroll, J. H., Seinfeld, J. H., and Wennberg, P. O.: Isoprene photooxidation: new insights into the production of acids and organic nitrates, Atmos. Chem. Phys., 9, 1479-1501, doi:10.5194/acp-9-1479-2009, 2009.

Peeters, J., Müller, J.-F., Stavrakou, T., and Nguyen, V. S.: Hydroxyl Radical Recycling in Isoprene Oxidation Driven 
by Hydrogen Bonding and Hydrogen Tunneling: The Upgraded LIM1 Mechanism, J. Phys. Chem. A, 118, 8625-8643, doi:10.1021/jp5033146, 2014.

Perring, A. E., Bertram, T. H., Wooldridge, P. J., Fried, A., Heikes, B. G., Dibb, J., Crounse, J. D., Wennberg, P. O., Blake, N. J., Blake, D. R., Brune, W. H., Singh, H. B., and Cohen, R. C.: Airborne observations of total $\mathrm{RONO}_{2}$ : new constraints on the yield and lifetime of isoprene nitrates, Atmos. Chem. Phys., 9, 14511463, doi:10.5194/acp-9-1451-2009, 2009.

Perring, A. E., Bertram, T. H., Farmer, D. K., Wooldridge, P. J., Dibb, J., Blake, N. J., Blake, D. R., Singh, H. B., Fuelberg, H., Diskin, G., Sachse, G., and Cohen, R. C.: The production and persistence of $\Sigma \mathrm{RONO}_{2}$ in the Mexico City plume, Atmos. Chem. Phys., 10, 7215-7229, doi:10.5194/acp-10-72152010, 2010.

Perring, A. E., Pusede, S. E., and Cohen, R. C.: An Observational Perspective on the Atmospheric Impacts of Alkyl and Multifunctional Nitrates on Ozone and Secondary Organic Aerosol, Chem. Rev., 113, 5848-5870, doi:10.1021/cr300520x, 2013.

Pusede, S. E., Gentner, D. R., Wooldridge, P. J., Browne, E. C., Rollins, A. W., Min, K.-E., Russell, A. R., Thomas, J., Zhang, L., Brune, W. H., Henry, S. B., DiGangi, J. P., Keutsch, F. N., Harrold, S. A., Thornton, J. A., Beaver, M. R., St. Clair, J. M., Wennberg, P. O., Sanders, J., Ren, X., VandenBoer, T. C., Markovic, M. Z., Guha, A., Weber, R., Goldstein, A. H., and Cohen, R. C.: On the temperature dependence of organic reactivity, nitrogen oxides, ozone production, and the impact of emission controls in San Joaquin Valley, California, Atmos. Chem. Phys., 14, 3373-3395, doi:10.5194/acp-14-3373-2014, 2014.

Pye, H. O. T., Luecken, D. J., Xu, L., Boyd, C. M., Ng, N. L., Baker, K. R., Ayres, B. R., Bash, J. O., Baumann, K., Carter, W. P. L., Edgerton, E. S., Fry, J. L., Hutzell, W. T., Schwede, D., and Shepson, P. B.: Modeling the Current and Future Roles of Particulate Organic Nitrates in the Southeastern United States, Environ. Sci. Technol., 49, 14195-14203, doi:10.1021/acs.est.5b03738, 2015.

Reuter, M., Buchwitz, M., Hilboll, A., Richter, A., Schneising, O., Hilker, M., Heymann, J., Bovensmann, H., and Burrows, J. P.: Decreasing emissions of $\mathrm{NO}_{x}$ relative to $\mathrm{CO}_{2}$ in East Asia inferred from satellite observations, Nat. Geosci., 7, 792-795, doi:10.1038/ngeo2257, 2014

Rindelaub, J. D., McAvey, K. M., and Shepson, P. B.: The photochemical production of organic nitrates from $\alpha$-pinene and loss via acid-dependent particle phase hydrolysis, Atmos. Environ., 100, 193-201, doi:10.1016/j.atmosenv.2014.11.010, 2015.

Rivera-Rios, J. C., Nguyen, T. B., Crounse, J. D., Jud, W., St. Clair, J. M., Mikoviny, T., Gilman, J. B., Lerner, B. M., Kaiser, J. B., de Gouw, J., Wisthaler, A., Hansel, A., Wennberg, P. O., Seinfeld, J. H., and Keutsch, F. N.: Conversion of hydroperoxides to carbonyls in field and laboratory instrumentation: Observational bias in diagnosing pristine versus anthropogenically controlled atmospheric chemistry, Geophys. Res. Lett., 41, 86458651, doi:10.1002/2014GL061919, 2014.

Rohrer, F., Lu, K., Hofzumahaus, A., Bohn, B., Brauers, T., Chang, C.-C., Fuchs, H., Häseler, R., Holland, F., Hu, M., Kita, K., Kondo, Y., Li, X., Lou, S., Oebel, A., Shao, M., Zeng, L., Zhu, T., Zhang, Y., and Wahner, A.: Maximum efficiency in the hydroxylradical-based self-cleansing of the troposphere, Nat. Geosci., 7, 559-563, doi:10.1038/ngeo2199, 2014.
Rollins, A. W., Smith, J. D., Wilson, K. R., and Cohen, R. C.: Real Time In Situ Detection of Organic Nitrates in Atmospheric Aerosols, Environ. Sci. Technol., 44, 5540-5545, doi:10.1021/es100926x, 2010.

Russell, A. R., Valin, L. C., and Cohen, R. C.: Trends in OMI NO observations over the United States: effects of emission control technology and the economic recession, Atmos. Chem. Phys., 12, 12197-12209, doi:10.5194/acp-12-12197-2012, 2012.

Russo, R. S., Zhou, Y., Haase, K. B., Wingenter, O. W., Frinak, E. K., Mao, H., Talbot, R. W., and Sive, B. C.: Temporal variability, sources, and sinks of $\mathrm{C}_{1}-\mathrm{C}_{5}$ alkyl nitrates in coastal New England, Atmos. Chem. Phys., 10, 1865-1883, doi:10.5194/acp10-1865-2010, 2010.

Ryerson, T. B., Buhr, M. P., Frost, G. J., Goldan, P. D., Holloway, J. S., Hübler, G., Jobson, B. T., Kuster, W. C., McKeen, S. A., Parrish, D. D., Roberts, J. M., Sueper, D. T., Trainer, M., Williams, J., and Fehsenfeld, F. C.: Emissions lifetimes and ozone formation in power plant plumes, J. Geophys. Res., 103, 22569-22583, doi:10.1029/98JD01620, 1998.

Ryerson, T. B., Trainer, M., Angevine, W. M., Brock, C. A., Dissly, R. W., Fehsenfeld, F. C., Frost, G. J., Goldan, P. D., Holloway, J. S., Hübler, G., Jakoubek, R. O., Kuster, W. C., Neuman, J. A., Nicks Jr., D. K., Parrish, D. D., Roberts, J. M., Sueper, D. T., Atlas, E. L., Donnelly, S. G., Flocke, F., Fried, A., Potter, W. T., Schauffler, S., Stroud, V., Weinheimer, A. J., Wert, B. P., Wiedinmyer, C., Alvarez, R. J., Banta, R. M., Darby, L. S., and Senff, C. J.: Effect of petrochemical industrial emissions of reactive alkenes and $\mathrm{NO}_{x}$ on tropospheric ozone formation in Houston, Texas, J. Geophys. Res., 108, 4249, doi:10.1029/2002JD003070, 2003.

Saunders, S. M., Jenkin, M. E., Derwent, R. G., and Pilling, M. J.: Protocol for the development of the Master Chemical Mechanism, MCM v3 (Part A): tropospheric degradation of nonaromatic volatile organic compounds, Atmos. Chem. Phys., 3, 161-180, doi:10.5194/acp-3-161-2003, 2003.

Schneider, M., Luxenhofer, O., Deissler, A., and Ballschmiter, K.: $\mathrm{C}_{1}-\mathrm{C}_{15}$ Alkyl Nitrates, Benzyl Nitrate, and Bifunctional Nitrates: Measurements in California and South Atlantic Air and Global Comparison Using $\mathrm{C}_{2} \mathrm{Cl}_{4}$ and $\mathrm{CHBr}_{3}$ as Marker Molecules, Environ. Sci. Technol., 32, 3055-3062, doi:10.1021/es980132g, 1998.

Teng, A. P., Crounse, J. D., Lee, L., St. Clair, J. M., Cohen, R. C., and Wennberg, P. O.: Hydroxy nitrate production in the $\mathrm{OH}-$ initiated oxidation of alkenes, Atmos. Chem. Phys., 15, 42974316, doi:10.5194/acp-15-4297-2015, 2015.

Thornton, J. A., Wooldridge, P. J., and Cohen, R. C.: Atmospheric $\mathrm{NO}_{2}$ : In Situ Laser-Induced Fluorescence Detection at Parts per Trillion Mixing Ratios, Anal. Chem., 72, 528-539, doi:10.1021/ac9908905, 2000.

Valin, L. C., Russell, A. R., and Cohen, R. C.: Variations of OH radical in an urban plume inferred from $\mathrm{NO}_{2}$ column measurements, Geophys. Res. Lett., 40, 1856-1860, doi:10.1002/grl.50267, 2013.

Washenfelder, R. A., Wagner, N. L., Dube, W. P., and Brown, S. S.: Measurement of Atmospheric Ozone by Cavity Ringdown Spectroscopy, Environ. Sci. Technol., 45, 2938-2944, doi:10.1021/es103340u, 2011

Wolfe, G. M., Thornton, J. A., Yatavelli, R. L. N., McKay, M., Goldstein, A. H., LaFranchi, B., Min, K.-E., and Cohen, R. C.: Eddy 
covariance fluxes of acyl peroxy nitrates (PAN, PPN and MPAN) above a Ponderosa pine forest, Atmos. Chem. Phys., 9, 615-634, doi:10.5194/acp-9-615-2009, 2009.

Xiong, F., McAvey, K. M., Pratt, K. A., Groff, C. J., Hostetler, M. A., Lipton, M. A., Starn, T. K., Seeley, J. V., Bertman, S. B., Teng, A. P., Crounse, J. D., Nguyen, T. B., Wennberg, P. O., Misztal, P. K., Goldstein, A. H., Guenther, A. B., Koss, A. R., Olson, K. F., de Gouw, J. A., Baumann, K., Edgerton, E. S., Feiner, P. A., Zhang, L., Miller, D. O., Brune, W. H., and Shepson, P. B.: Observation of isoprene hydroxynitrates in the southeastern United States and implications for the fate of $\mathrm{NO}_{x}$, Atmos. Chem. Phys., 15, 11257-11272, doi:10.5194/acp-15-11257-2015, 2015.
Xiong, F., Borca, C. H., Slipchenko, L. V., and Shepson, P. B.: Photochemical degradation of isoprene-derived 4,1-nitrooxy enal, Atmos. Chem. Phys., 16, 5595-5610, doi:10.5194/acp-16-55952016, 2016.

Zalakeviciute, R., Alexander, M. L., Allwine, E., Jimenez, J. L., Jobson, B. T., Molina, L. T., Nemitz, E., Pressley, S. N., VanReken, T. M., Ulbrich, I. M., Velasco, E., and Lamb, B. K.: Chemically-resolved aerosol eddy covariance flux measurements in urban Mexico City during MILAGRO 2006, Atmos. Chem. Phys., 12, 7809-7823, doi:10.5194/acp-12-7809-2012, 2012. 